\title{
Novel Lysine-Rich Delivery Peptides of Plant Origin ERD and Human S100: The Effect of Carboxyfluorescein Conjugation, Influence of Aromatic and Proline Residues, Cellular Internalization and Penetration Ability
}

Fanni Sebák, ${ }^{1,2}$ Lilla Borbála Horváth, ${ }^{3,4,5}$ Dániel Kovács, ${ }^{1,5}$ János Szolomájer, ${ }^{6}$ Gábor K. Tóth, ${ }^{6}$ Ákos Babiczky, ${ }^{7,8}$ Szilvia Bösze, ${ }^{3,4}$ Andrea Bodor ${ }^{1 *}$

${ }^{1}$ Institute of Chemistry, ELTE - Eötvös Loránd University, Pázmány Péter sétány 1/a, H-1117 Budapest, Hungary

${ }^{2}$ Doctoral School of Pharmaceutical Sciences, Semmelweis University, Üllői út 26, H-1085 Budapest, Hungary

${ }^{3}$ ELKH-ELTE Research Group of Peptide Chemistry, Eötvös Loránd Research Network, Eötvös Loránd University, Pázmány Péter sétány 1/a, H-1117 Budapest, Hungary

${ }^{4}$ National Public Health Center, Albert Flórián út 2-6, Budapest, H-1097, Hungary

${ }^{5}$ Hevesy György PhD School of Chemistry, ELTE Eötvös Loránd University, Pázmány Péter sétány 1/a, H-1117 Budapest, Hungary

${ }^{6}$ Department of Medical Chemistry, University of Szeged, Dóm tér 8, H-6720 Szeged, Hungary

${ }^{7}$ Institute of Cognitive Neuroscience and Psychology, Research Centre for Natural Sciences, Magyar tudósok körútja 2, H-1117, Budapest, Hungary

${ }^{8}$ Doctoral School of Psychology/Cognitive Science, Budapest University of Technology and Economics, Műegyetem rakpart 3., H-1111, Budapest, Hungary 


\section{Table of contents}

S1. Chemical characterization of the peptides and Cf-conjugated peptide derivatives ............ 3

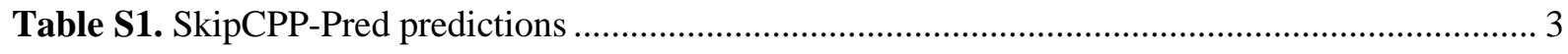

Table S2. Analytical evaluation of ERD and S100 synthetic peptides ............................................... 4

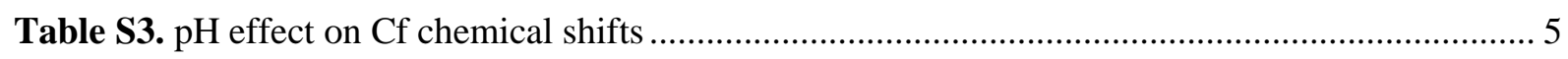

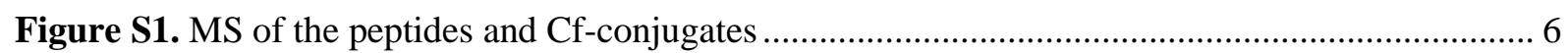

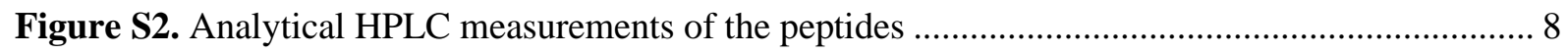

Figure S3. Analytical HPLC measurements of the Cf-conjugated peptide derivatives.......................... 9

S2. Fluorescence intensity studies of Cf-conjugated peptide derivatives................................. 10

Figure S4. Fluorescence emission spectra for each Cf-conjugated peptide ....................................... 10

Figure S5. Fluorescence emission spectra at different $\mathrm{pH}$ values .................................................. 11

S3. NMR studies of peptides and Cf-peptide derivatives ....................................................... 12

Figure S6. NMR spectra of the peptides and Cf-conjugated derivatives............................................ 12

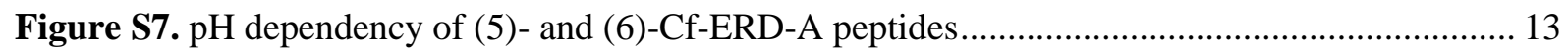

Figure S8. pH dependency of (5)- and (6)-Cf-ERD-B peptides ....................................................... 14

S4. In vitro cellular uptake and internalization studies of $\mathrm{Cf}$-conjugated peptide derivatives 15

Figure S9. In vitro cellular uptake on MonoMac6 cells ................................................................ 15

Figure S10. In vitro cellular uptake rate of Cf-peptides using different incubation times with trypsin on A431 cells.

Figure S11. In vitro cellular uptake on MonoMac6 cells using trypan blue to quench external fluorescence...

Figure S12. In vitro cellular uptake on A431 cells using trypan blue to quench external fluorescence 18

Figure S13. Time dependency of cellular uptake on A431 cells ...................................................... 19

Figure S14. Internalization of Cf-peptides on MonoMac6 cells visualized by CLSM ....................... 20

Figure S15. Internalization of Cf-peptides on A431 cells visualized by CLSM ................................. 21

Figure S16. Intracellular localization of (6)-Cf-peptides on A431 cells visualized by CLSM ............ 22

Figure S17. Intracellular localization of (5)-Cf-peptides on A431 cells visualized by CLSM ............ 23

S5. In vitro cytotoxic activity of different inhibitor compounds .............................................. 24

Table S4. In vitro cytotoxic effect of different inhibitors on A431 cells .............................................. 24

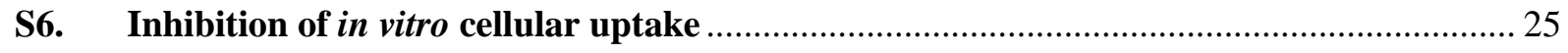

Figure S18. Chemical inhibition of in vitro cellular uptake on A431 cells determined by flow

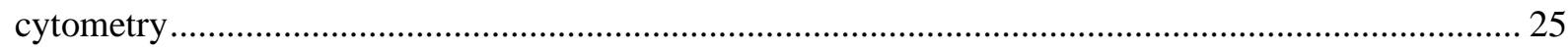

Figure S19. Suggested internalization paths and in vitro cellular uptake determined at low temperature

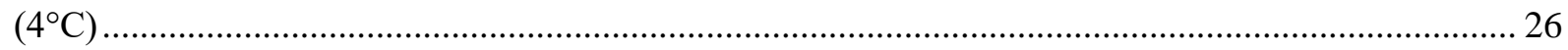

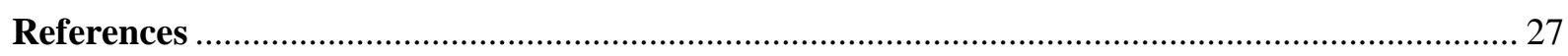


S1. Chemical characterization of the peptides and Cf-conjugated peptide derivatives

Table S1. SkipCPP-Pred predictions

\begin{tabular}{|c|c|c|c|}
\hline Peptide & Sequence & Predicted class & Prediction confidence \\
\hline ERD-A & DRGLFDFLGKKK & cell-penetrating & 0.81 \\
\hline ERD-B & EKKGFMEKLKEKLPG & cell-penetrating & 0.51 \\
\hline ERD-C & EKKGILEKIKEKLPG & cell-penetrating & 0.81 \\
\hline S100 & FFEGFPDKQPRKK & cell-penetrating & 0.59 \\
\hline
\end{tabular}

The predictions were done using the SkipCPP webserver ${ }^{1}$ (http://server.malab.cn/SkipCPPPred/Index.html). 
Table S2. Analytical evaluation of ERD and S100 synthetic peptides

\begin{tabular}{|c|c|c|c|c|}
\hline Code & $\begin{array}{l}M_{\text {calc(mono) }} \\
M_{\text {meas }}{ }^{a}\end{array}$ & $\begin{array}{c}R_{\mathrm{t}} \\
(\min )^{\mathrm{b}}\end{array}$ & Amino acid analysis ${ }^{c}$ & $\begin{array}{l}\text { peptide } \\
\text { content } \\
(\%)^{\mathrm{d}}\end{array}$ \\
\hline ERD-A & $\begin{array}{c}1422.787 \\
/ 1422.650\end{array}$ & 15.1 & $\begin{array}{l}\text { Asp [2;1.96], Gly [2;2.01], } \\
\text { Leu }[2 ; 1.95], \text { Phe }[2 ; 1.92], \\
\text { Lys }[3 ; 2.77], \text { Arg }[1 ; 0.96]\end{array}$ & 65 \\
\hline ERD-B & $\begin{array}{c}1760.975 \\
/ 1760.933\end{array}$ & 14.4 & $\begin{array}{c}\text { Glu [3;2.95], Pro }[1 ; 0.95], \\
\text { Gly }[2 ; 1.93] \text {, Met }[1 ; 0.70], \\
\text { Leu }[2 ; 1.98], \text { Phe }[1 ; 0.92] \text { Lys }[5 ; 4.78]\end{array}$ & 64 \\
\hline ERD-C & $\begin{array}{l}1709.035 \\
/ 1709.06\end{array}$ & 14.9 & $\begin{array}{c}\text { Glu }[3 ; 2.89] \text {, Pro }[1 ; 0.92], \\
\text { Gly [2;1.96], Ile [2;1.97], } \\
\text { Leu }[2 ; 1.95], \text { Lys }[5 ; 4.77]\end{array}$ & 65 \\
\hline S100 & $\begin{array}{c}1622.846 \\
/ 1622.400\end{array}$ & 13.0 & $\begin{array}{c}\text { Asp [1;0.97], Glu* [2;2.02], } \\
\text { Pro [2;1,96], Gly [1;0.92], } \\
\text { Phe [3;2.86], Lys [3;2.77], } \\
\text { Arg [1;0.95] }\end{array}$ & 68 \\
\hline (6)-Cf-ERD-A & $\begin{array}{c}1781.107 \\
/ 1781.013\end{array}$ & 18.1 & $\begin{array}{c}\text { Asp [2;2.04], Gly [2;2.06], } \\
\text { Leu }[2 ; 1.94], \text { Phe }[2 ; 1.92], \\
\text { Lys }[3 ; 2.65] \text {, Arg }[1 ; 0.97]\end{array}$ & 68 \\
\hline (6)-Cf-ERD-B & $\begin{array}{c}2119.295 \\
/ 2119.155\end{array}$ & 16.7 & $\begin{array}{c}\text { Glu [3;2.87], Pro [1;0.95], } \\
\text { Gly [2;1.95], Met }[1 ; 0.71], \\
\text { Leu [2; } 1.93], \text { Phe [1;0.94] Lys [5; 4.67] }\end{array}$ & 67 \\
\hline (6)-Cf-ERD-C & $\begin{array}{c}2067.355 \\
/ 2067.307\end{array}$ & 17.0 & $\begin{array}{c}\text { Glu [3;2.89], Pro }[1 ; 0.91], \\
\text { Gly [2; } 1.89], \text { Ile }[2 ; 1.87], \text { Leu }[2 ; 2.01], \\
\text { Lys }[5 ; 4.67]\end{array}$ & 65 \\
\hline (6)-Cf-S100 & $\begin{array}{c}1981.166 \\
/ 1981.277\end{array}$ & 17.9 & $\begin{array}{c}\text { Asp [1;0.97], Glu* [2;2.10], } \\
\text { Pro [2;1.88], Gly [1;0.94], } \\
\text { Phe [3; 2.88], Lys [3;2.85], Arg [1;0.95] }\end{array}$ & 65 \\
\hline (5)-Cf-ERD-A & $\begin{array}{c}1781.107 \\
/ 1780.943\end{array}$ & 18.3 & $\begin{array}{l}\text { Asp }[2 ; 1.93] \text {, Gly }[2 ; 2.10], \\
\text { Leu }[2 ; 1.89] \text {, Phe }[2 ; 1.87], \\
\text { Lys }[3 ; 3.05] \text {, Arg }[1 ; 1.05]\end{array}$ & 68 \\
\hline (5)-Cf-ERD-B & $\begin{array}{l}2119.295 \\
/ 2119.500\end{array}$ & 16.9 & $\begin{array}{c}\text { Glu [3;3.10], Pro }[1 ; 0.95], \\
\text { Gly }[2 ; 2.09], \text { Met }[1 ; 0.96], \\
\text { Leu [2; } 1.91], \text { Phe }[1 ; 0.95] \text { Lys }[5 ; 4.88]\end{array}$ & 63 \\
\hline (5)-Cf-ERD-C & $\begin{array}{l}2067.355 \\
/ 2067.453\end{array}$ & 17.2 & $\begin{array}{c}\text { Glu [3;3.15], Pro [1;0.96], } \\
\text { Gly [2; } 2.10], \text { Ile [2;1.97], Leu [2;1.96], } \\
\text { Lys }[5 ; 4.96]\end{array}$ & 66 \\
\hline (5)-Cf-S100 & $\begin{array}{c}1981.166 \\
/ 1981.100\end{array}$ & 18.3 & $\begin{array}{c}\text { Asp [1;1.04], Glu* [2;2.03], } \\
\text { Pro [2;2.00], Gly [1;0.98], } \\
\text { Phe [3; 2.89], Lys [3;2.77], Arg [1;0.96] }\end{array}$ & 67 \\
\hline
\end{tabular}

All peptides were amidated on the C-terminus and isolated as TFA salt.

${ }^{a}$ ESI-MS using Waters SQ detector (Milford, MA, USA).

${ }^{\mathrm{b}}$ Retention times were determined using Exformma EX1600 analytical HPLC with YMC-Pack ODS-A C18 (100 A, $4.6 \times 150 \mathrm{~mm}$ ) column. Flow rate: $1 \mathrm{~mL} / \mathrm{min}$, detector: $\lambda=220 \mathrm{~nm}$, gradient: $0-20 \mathrm{~min} 5$ 65 B\%. A eluent: 0.1\% (v/v) TFA in dd $\mathrm{H}_{2} \mathrm{O}$, B eluent: 0.1\% (v/v) TFA in acetonitrile $\mathrm{H}_{2} \mathrm{O}$ 80:20 (v/v). ${ }^{c}$ Amino acid content was determined by amino acid analysis using a Sykam Amino Acid $\mathrm{S} 433 \mathrm{H}$ analyzer equipped with an ion-exchange separation column and post-column derivatization. Prior to analysis, samples were hydrolyzed with $6 \mathrm{M} \mathrm{HCl}$ in sealed and evacuated tubes at $110^{\circ} \mathrm{C}$ for $24 \mathrm{~h}$. For post-column derivatization the ninhydrin-method was used. * Gln was determined as glutamic acid. Sequence of peptides: ERD-A: DRGLFDFLGKKK, ERD-B: EKKGFMEKLKEKLPG, ERD-C: EKKGILEKIKEKLPG, S100: FFEGFPDKQPRKK.

${ }^{\mathrm{d}}$ Peptide content was determined by amino acid analysis from the freeze-dried purified final product. 
Table S3. $\mathrm{pH}$ effect on $\mathrm{Cf}$ chemical shifts

\begin{tabular}{|c|c|c|c|}
\hline Sample & $\delta\left({ }^{13} \mathrm{C}^{I 2}\right) / \mathrm{ppm}$ & $\delta\left({ }^{1} \mathrm{H}^{I 2}\right) / \mathrm{ppm}$ & $\delta\left({ }^{13} \mathrm{C}^{13}\right) / \mathrm{ppm}$ \\
\hline 5(6)-Cf in 25mM NaOH & 125.7 & 6.64 & 183.3 \\
\hline 5(6)-Cf in DMSO-d6 & 116.0 & 6.65 & 162.9 \\
\hline (5)-Cf-ERD-A, $\mathrm{pH}=3.0$ & 121.0 & 6.76 & no data \\
\hline (5)-Cf-ERD-A, $\mathrm{pH}=5.0$ & 123.5 & 6.70 & no data \\
\hline (5)-Cf-ERD-A, $\mathrm{pH}=7.0$ & 125.5 & 6.61 & no data \\
\hline (6)-Cf-ERD-A, $\mathrm{pH}=3.0$ & 121.7 & 6.73 & 172.9 \\
\hline (6)-Cf-ERD-A, $\mathrm{pH}=5.0$ & 123.6 & 6.66 & 176.8 \\
\hline (6)-Cf-ERD-A, $\mathrm{pH}=7.0$ & 125.6 & 6.56 & no data \\
\hline (6)-Cf-ERD-B, $\mathrm{pH}=3.0$ & 122.9 & 6.74 & no data \\
\hline (6)-Cf-ERD-B, $\mathrm{pH}=4.5$ & 124.0 & 6.72 & no data \\
\hline (6)-Cf-ERD-B, $\mathrm{pH}=6.0$ & 125.0 & 6.63 & no data \\
\hline (6)-Cf-ERDB, $\mathrm{pH}=7.0$ & 125.7 & 6.57 & no data \\
\hline (6)-Cf-ERD-B, $\mathrm{pH}=7.6$ & 125.8 & 6.55 & no data \\
\hline (5)-Cf-ERD-B, $\mathrm{pH}=3.0$ & 120.7 & 6.82 & 170.5 \\
\hline (5)-Cf-ERD-B, $\mathrm{pH}=4.0$ & 122.6 & 6.79 & no data \\
\hline (5)-Cf-ERD-B, $\mathrm{pH}=5.0$ & 123.9 & 6.78 & no data \\
\hline (5)-Cf-ERD-B, $\mathrm{pH}=6.0$ & 124.7 & 6.72 & no data \\
\hline (5)-Cf-ERD-B, $\mathrm{pH}=7.0$ & 125.6 & 6.63 & 182.1 \\
\hline (5)-Cf-ERD-B, $\mathrm{pH}=7.6$ & 125.6 & 6.63 & no data \\
\hline (6)-Cf-ERD-C, $\mathrm{pH}=3.0$ & 120.5 & 6.82 & no data \\
\hline (5)-Cf-ERD-C, $\mathrm{pH}=3.0$ & 120.6 & 6.85 & no data \\
\hline (5)-Cf-S100, $\mathrm{pH}=3.0$ & 119.7 & 6.75 & no data \\
\hline (6)-Cf-S100, $\mathrm{pH}=3.0$ & 120.0 & 6.75 & no data \\
\hline
\end{tabular}


Figure S1. MS of the peptides and Cf-conjugates

The identity of the peptides was proved by ESI-MS spectrometry using Waters SQ detector (Milford, MA, USA).
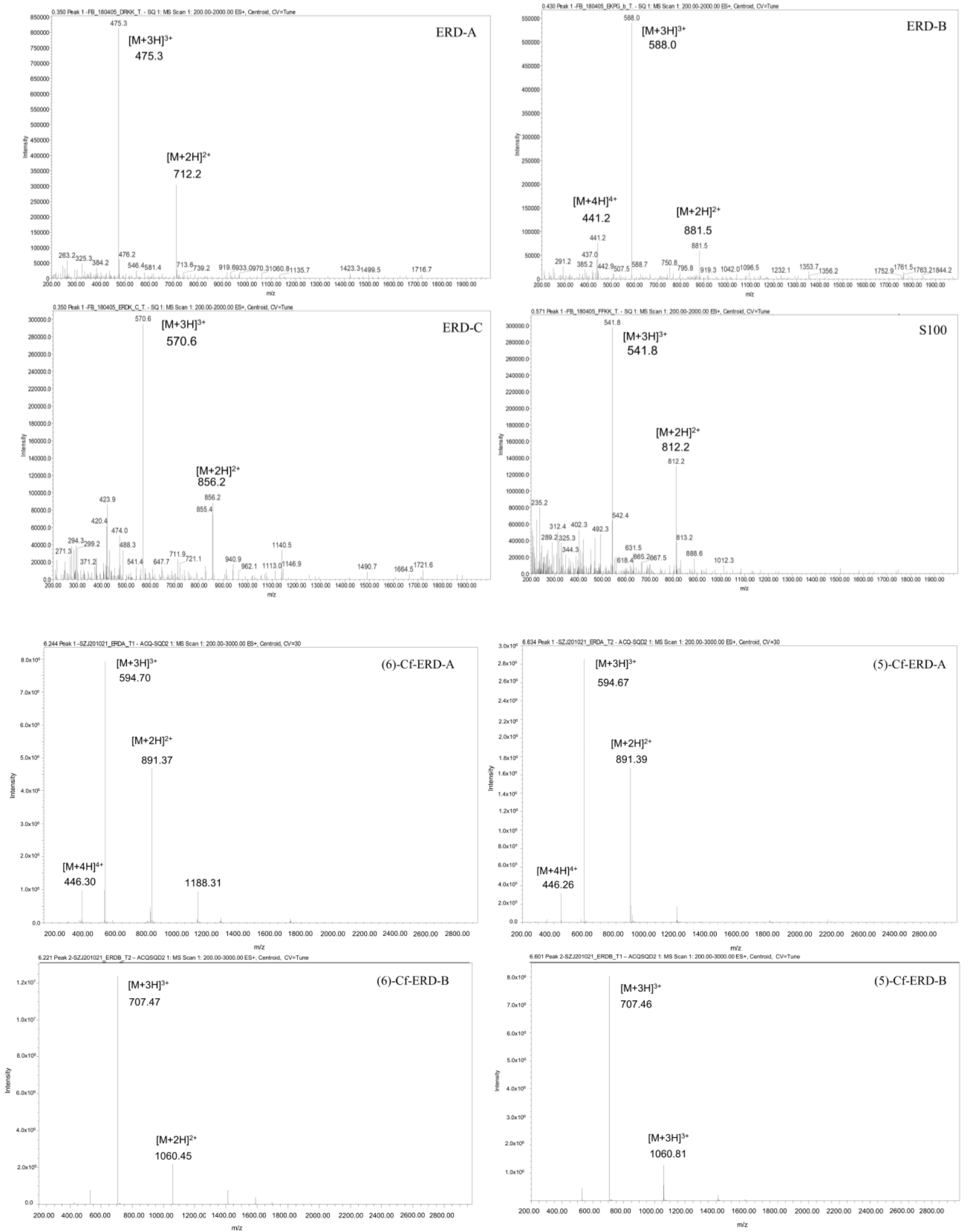

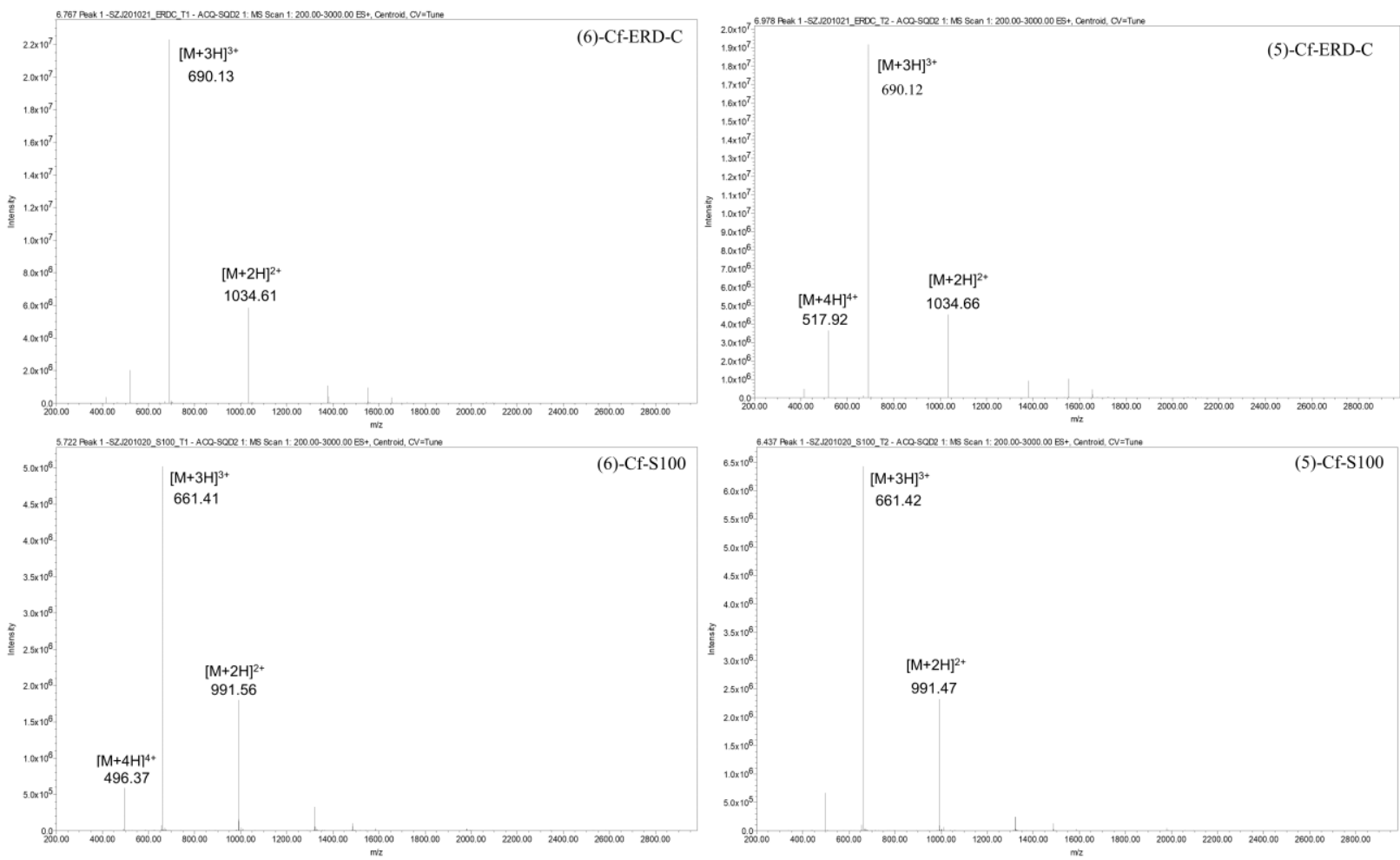
Figure S2. Analytical HPLC measurements of the peptides

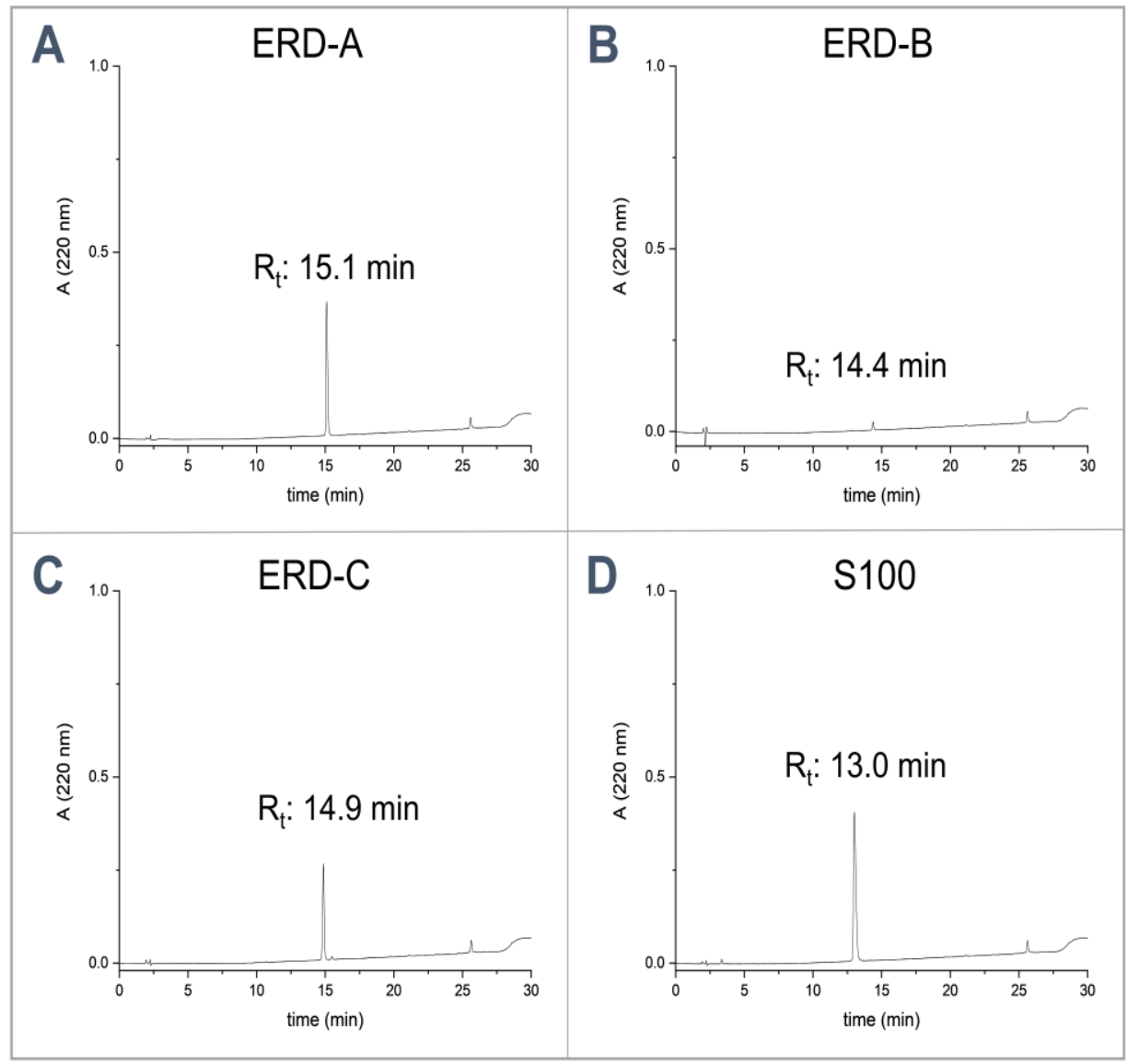

Figure S2. Analytical HPLC chromatograms of peptides. (A) ERD-A, (B) ERD-B, (C) ERD-C, (D) S100 peptide. Exformma EX1600 (Wufeng Scientific Instruments, Shanghai, China) analytical RPHPLC system with YMC-Pack ODS-A C18 (100 A, 4.6 x 150 mm) (YMC Co. Ltd., Kyoto, Japan) column. Gradient: 0-5 min 5\% B, 5-25 min 0-65\% B, 25-26 min 95\% B, flow rate: $1 \mathrm{~mL} / \mathrm{min}$, detector wavelength: $\lambda=220 \mathrm{~nm}$. Eluent A: distilled water with $0.1 \% \mathrm{TFA}(\mathrm{v} / \mathrm{v})$; eluent B: acetonitrile $/$ water $=$ $80: 20(\mathrm{v} / \mathrm{v})$ with $0.1 \%$ TFA. 
Figure S3. Analytical HPLC measurements of the Cf-conjugated peptide derivatives

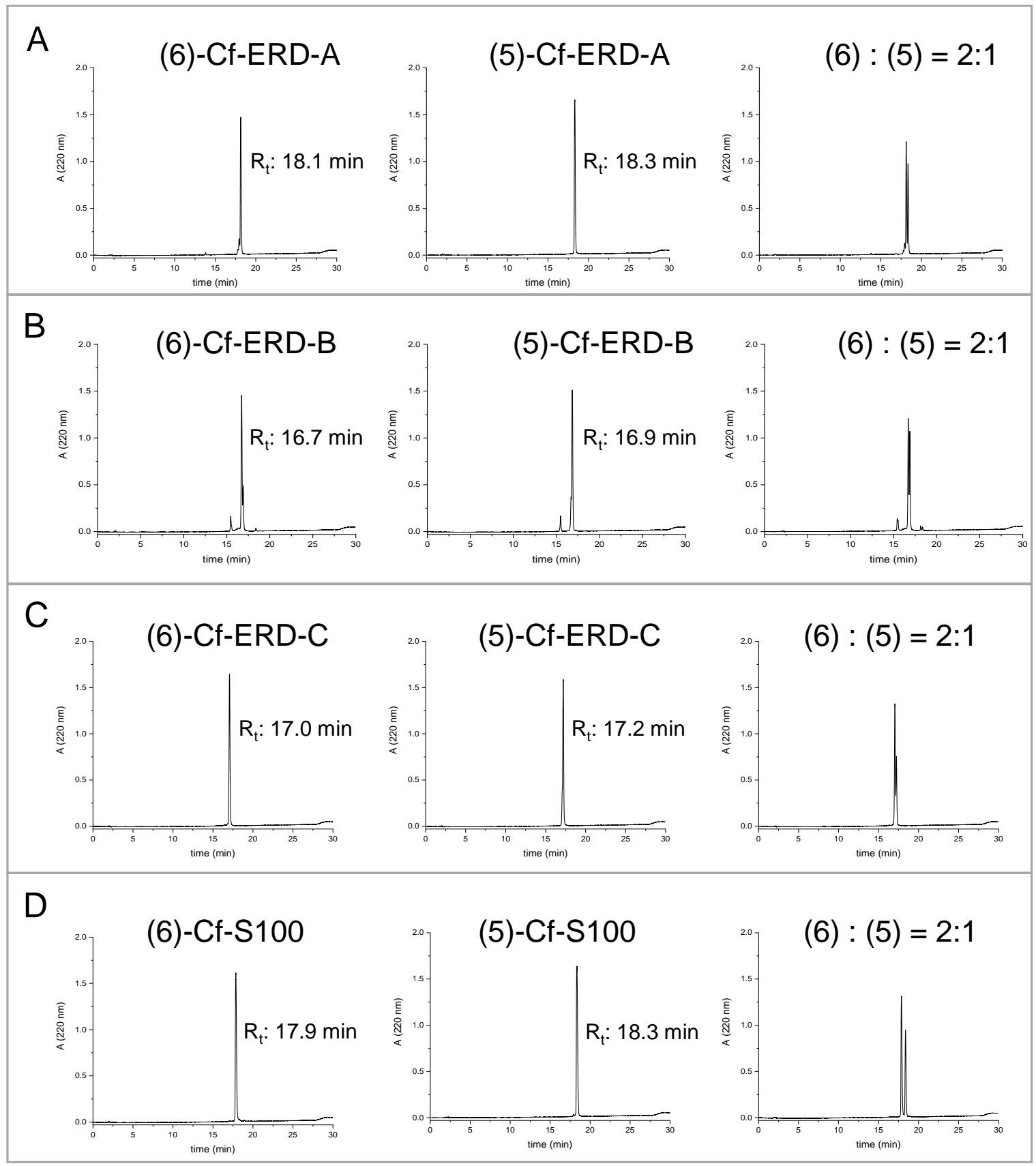

Figure S3. Analytical HPLC chromatograms of (6)-Cf and (5)-Cf isomers and co-injections. (A) ERDA, (B) ERD-B, (C) ERD-C, (D) S100 peptide. To compare the peptide content of the (6)-Cf and (5)-Cf isomers they were injected separately (concentration: $1 \mathrm{mg} / \mathrm{mL}$ ) and co-injected in a defined ratio to analytical HPLC system: Exformma EX1600 (Wufeng Scientific Instruments, Shanghai, China) analytical RP-HPLC system with YMC-Pack ODS-A C18 (100 A, 4.6 x $150 \mathrm{~mm}$ ) (YMC Co. Ltd., Kyoto, Japan) column. Gradient: 0-5 min 5\% B, 5-25 min 0-65\% B, 25-26 min 95\% B, flow rate: 1 $\mathrm{mL} / \mathrm{min}$, detector wavelength: $\lambda=220 \mathrm{~nm}$. Eluent A: distilled water with $0.1 \%$ TFA (v/v); eluent B: acetonitrile $/$ water $=80: 20(\mathrm{v} / \mathrm{v})$ with $0.1 \%$ TFA. 


\section{S2. Fluorescence intensity studies of Cf-conjugated peptide derivatives}

Cf-peptide derivatives' fluorescence intensity in the range of $\mathrm{pH}=4.0-7.6$ was determined using Varian Eclipse spectrofluorometer. Peptide concentration was $6.25 \mu \mathrm{M}$, different $\mathrm{pH}$ buffers were obtained by mixing $0.1 \mathrm{M}$ citric acid and $0.2 \mathrm{M} \mathrm{Na}_{2} \mathrm{HPO}_{4}$ solutions in a welldefined ratio. Excitation: $\lambda=488 \mathrm{~nm}$, emission: $\lambda=490-700 \mathrm{~nm}$, detector voltage: $450 \mathrm{~V}$ (in case of (6)-Cf-ERD-C also $400 \mathrm{~V}$ detector voltage was applied). Fluorescent properties of (5)and (6)-Cf were obtained as described earlier ${ }^{2}$.

Figure S4. Fluorescence emission spectra for each Cf-conjugated peptide
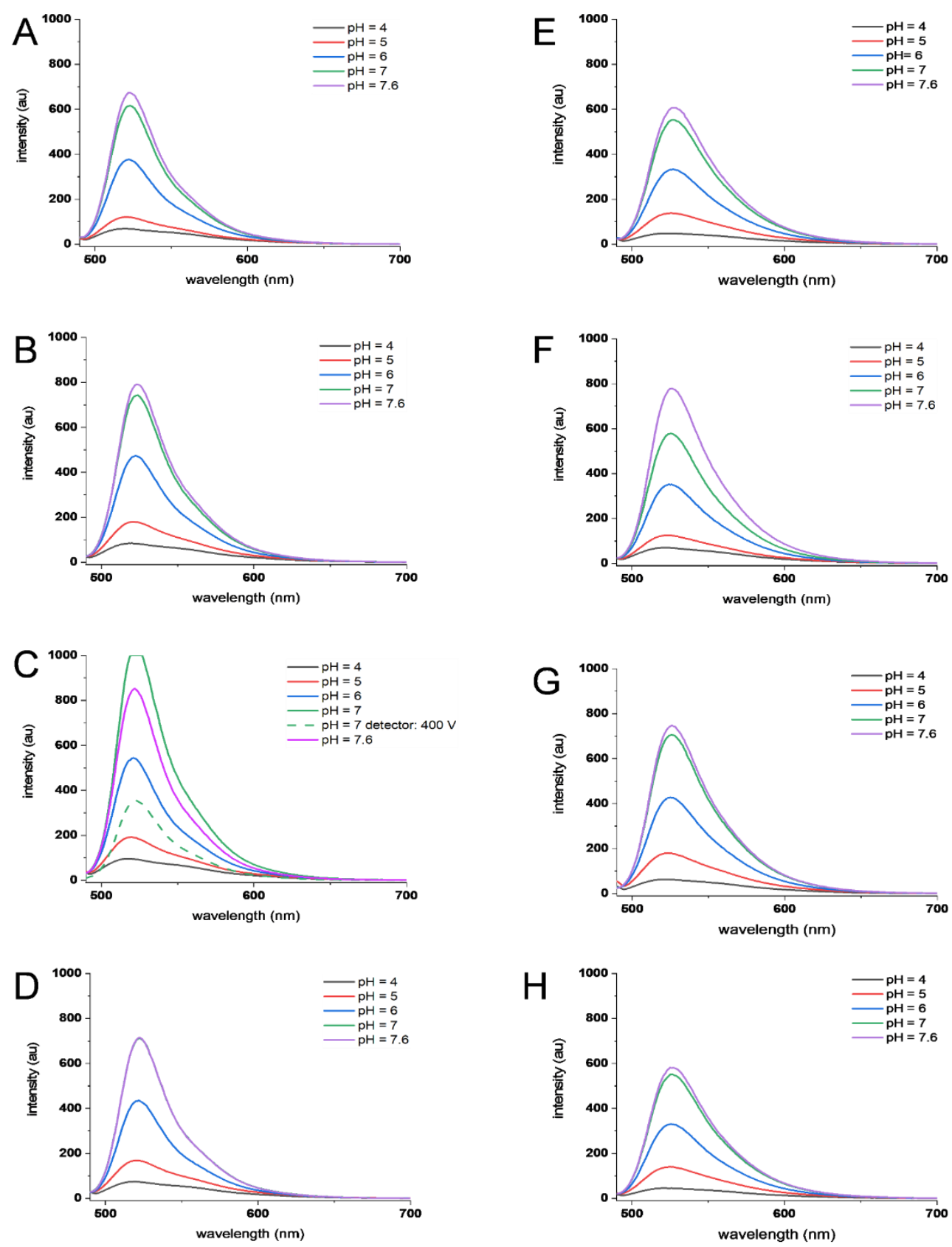

Figure S4. Emission fluorescence spectra of Cf-peptide derivatives in the range of $\mathrm{pH}=4.0-7.6$ (A) (6)-Cf-ERD-A, (B) (6)-Cf-ERD-B, (C) (6)-Cf-ERD-C, (D) (6)-Cf-S100, (E) (5)-Cf-ERD-A, (F) (5)-CfERD-B, (G) (5)-Cf-ERD-C, (H) (5)-Cf-S100. 
Figure S5. Fluorescence emission spectra at different $\mathrm{pH}$ values
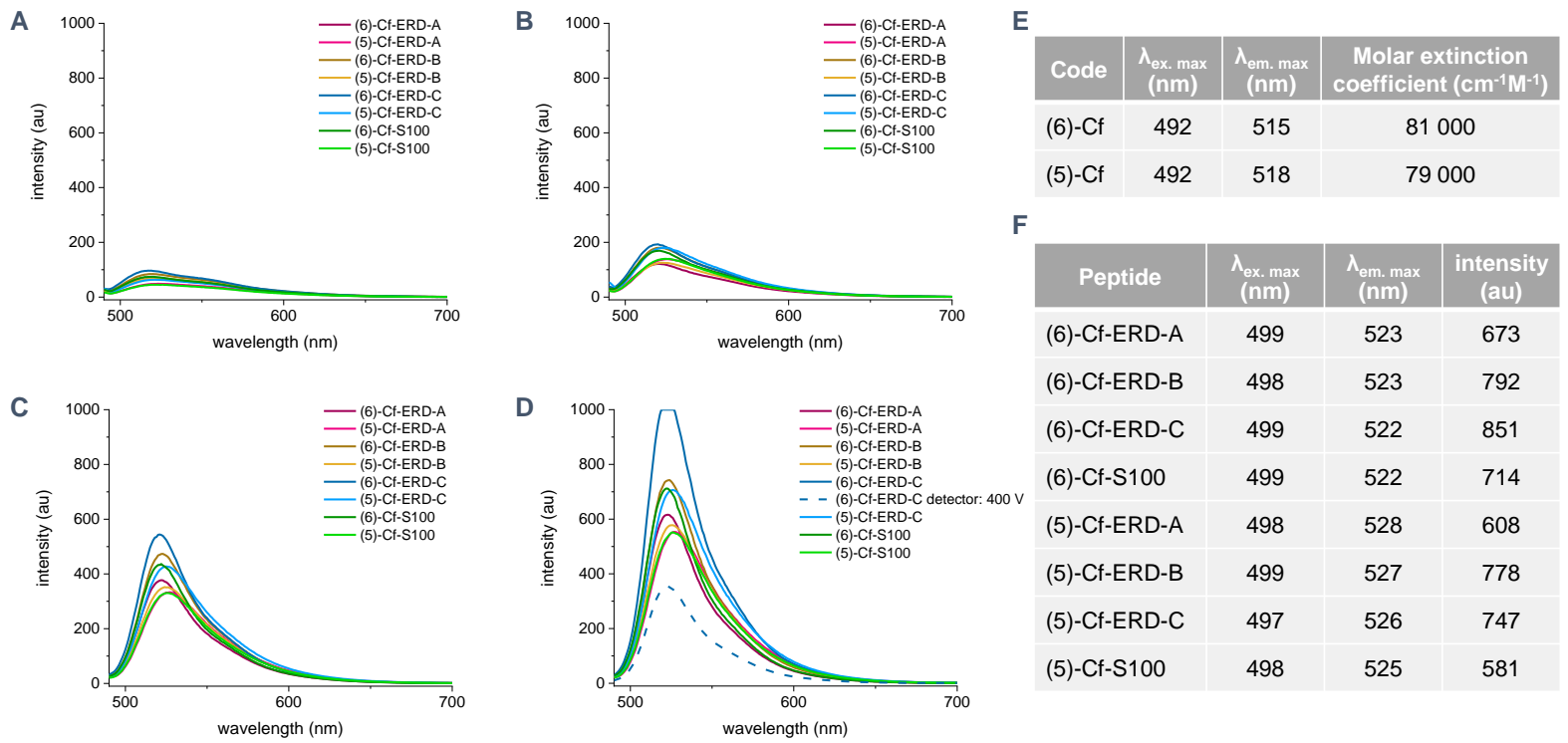

\begin{tabular}{|l|l|l|l|}
\hline$(6)-C f-E R D-B$ & 498 & 523 & 792 \\
\hline$(6)-C f-E R D-C$ & 499 & 522 & 851 \\
\hline$(6)-C f-S 100$ & 499 & 522 & 714 \\
\hline$(5)-C f-E R D-A$ & 498 & 528 & 608 \\
\hline$(5)-C f-E R D-B$ & 499 & 527 & 778 \\
\hline$(5)-C f-E R D-C$ & 497 & 526 & 747 \\
\hline$(5)-C f-S 100$ & 498 & 525 & 581 \\
\hline
\end{tabular}

Figure S5. Emission fluorescence spectra of Cf-peptides at (A) $\mathrm{pH}=4.0,(\mathrm{~B}) \mathrm{pH}=5.0,(\mathrm{C}) \mathrm{pH}=6.0$ and (D) $\mathrm{pH}=7.0$. Excitation: $\lambda=488 \mathrm{~nm}$, emission: $\lambda=490-700 \mathrm{~nm}$, detector voltage: $450 \mathrm{~V}$, peptide concentration: $6.25 \mu \mathrm{M}$. (E) fluorescence properties of (6)- and (5)-Cf, (F) emission and excitation maximum of Cf-peptides. 


\section{S3. NMR studies of peptides and Cf-peptide derivatives}

Figure S6. NMR spectra of the peptides and Cf-conjugated derivatives

A
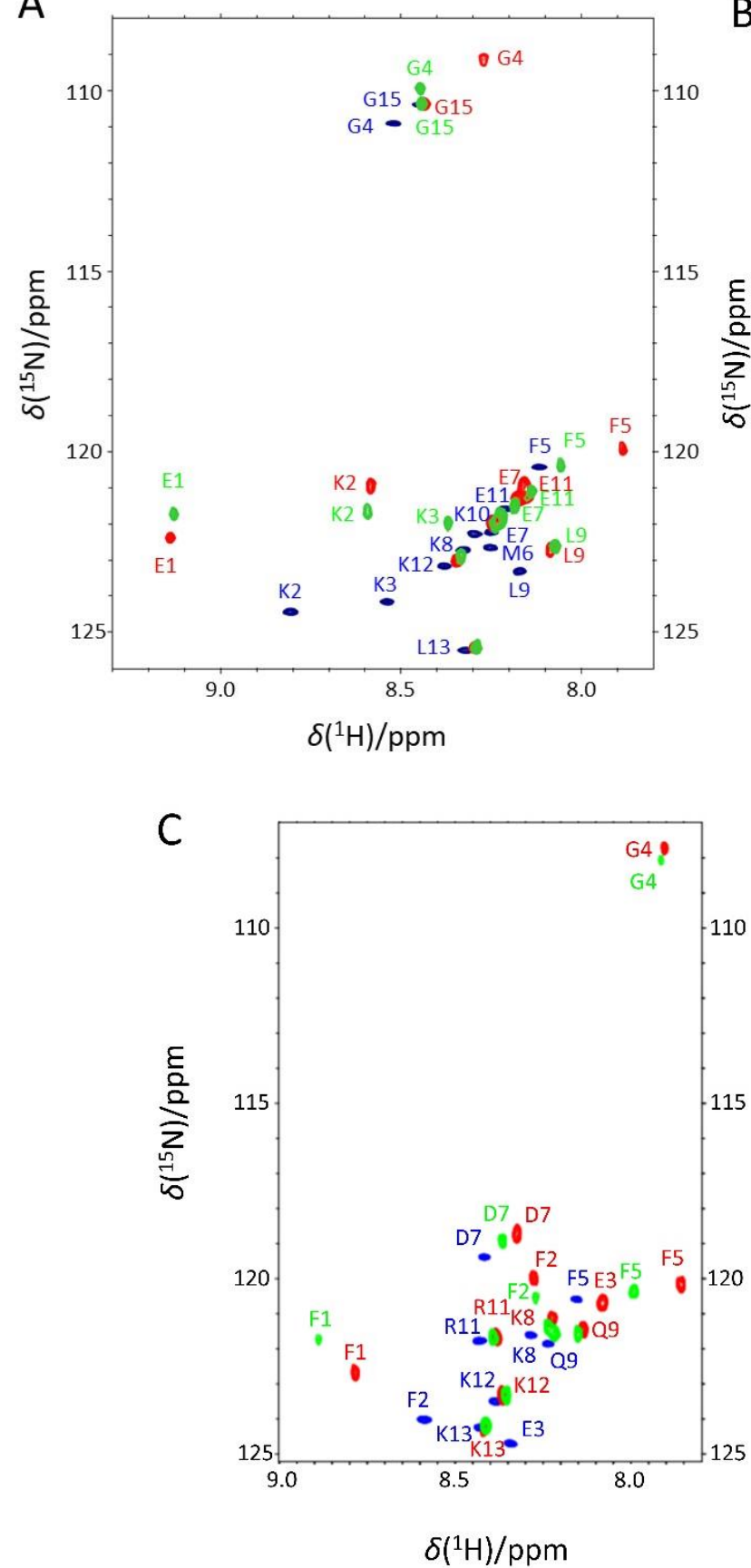

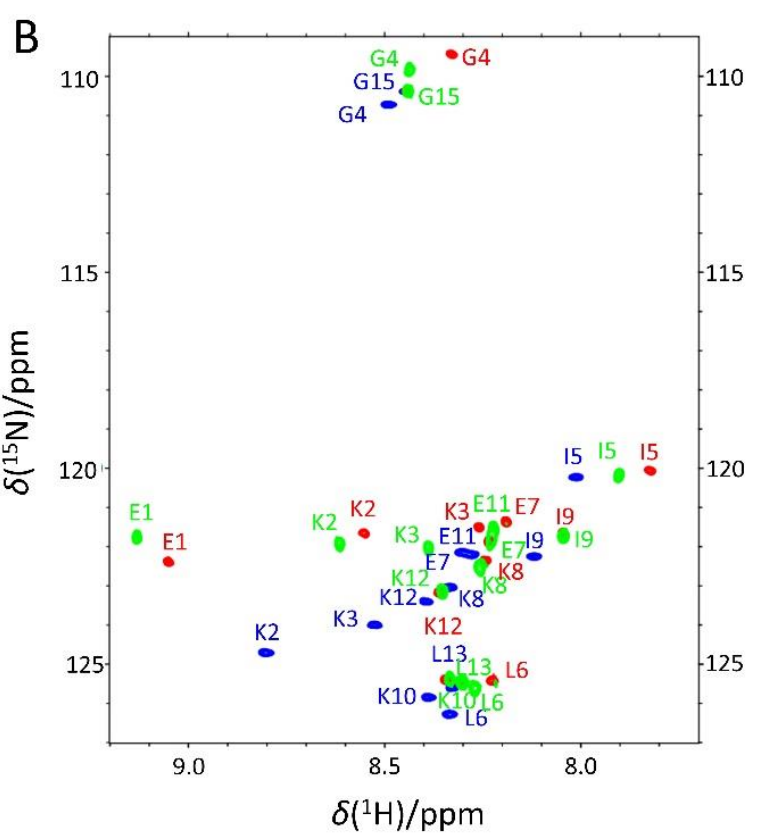

D

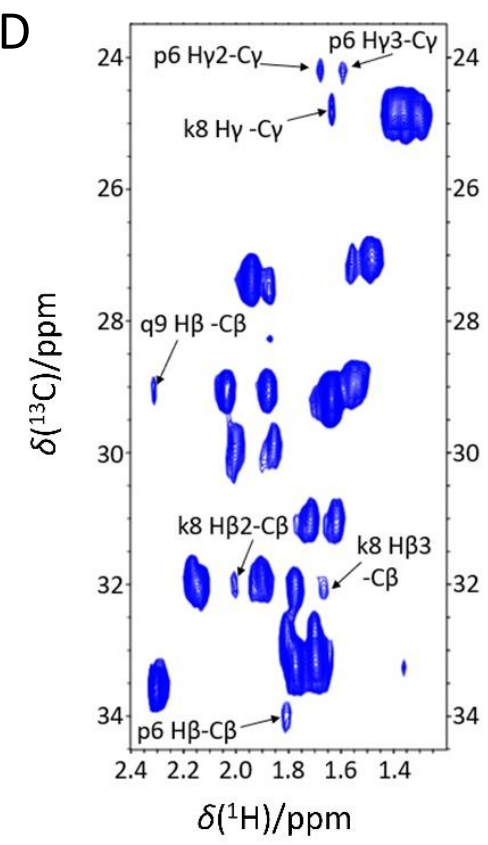

Figure S6. ${ }^{1} \mathrm{H},{ }^{15} \mathrm{~N}-\mathrm{SOFAST}-\mathrm{HMQC}$ spectra of the peptides (blue) and the $\mathrm{Cf}$-conjugated peptides (5Cf: green; 6-Cf: red) at $\mathrm{pH}=3$ : (A) ERD-B; (B) ERD-C; (C) $\mathrm{S} 100$ and (D) ${ }^{1} \mathrm{H},{ }^{13} \mathrm{C}-\mathrm{HSQC}$ spectrum of the (6)-Cf-S100 peptide aliphatic region highlighting the assignment for the minor peaks caused by P6 cis-trans isomerization. The minor conformer amino acids are shown with lower case letters. 
Figure S7. pH dependency of (5)- and (6)-Cf-ERD-A peptides

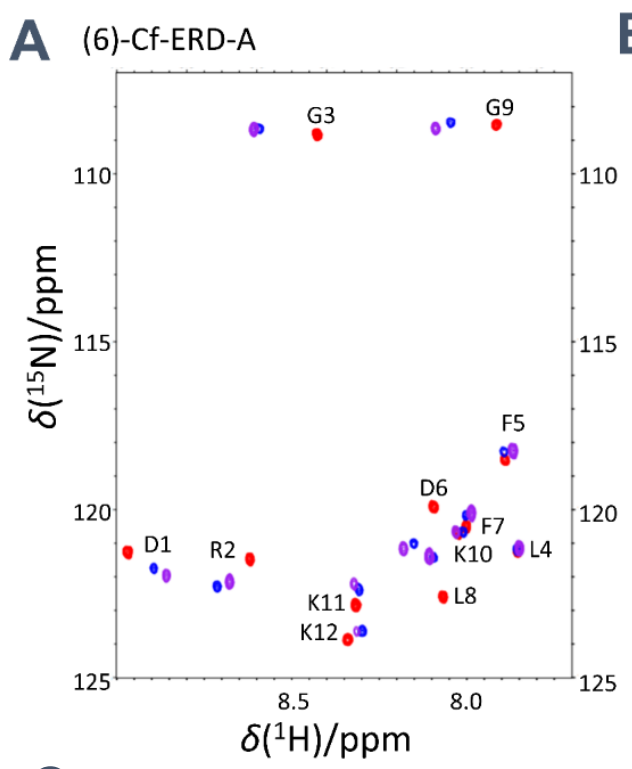

B (5)-Cf-ERD-A
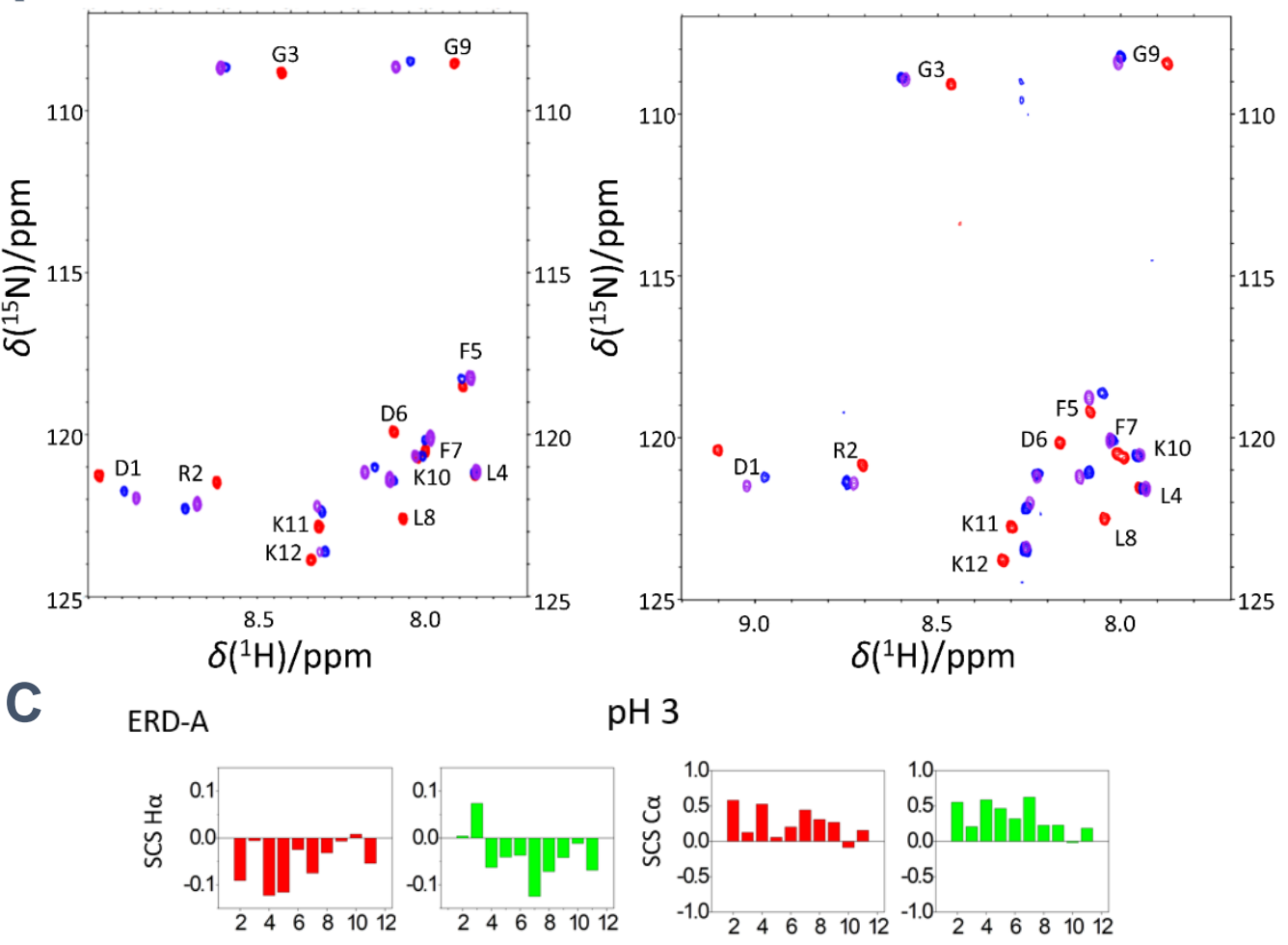

$\mathrm{pH} 3$

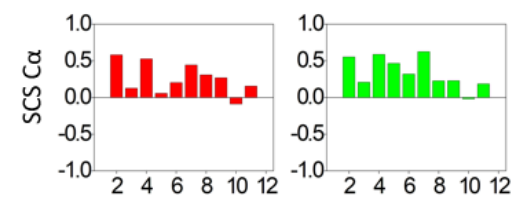

$\mathrm{pH} 5$
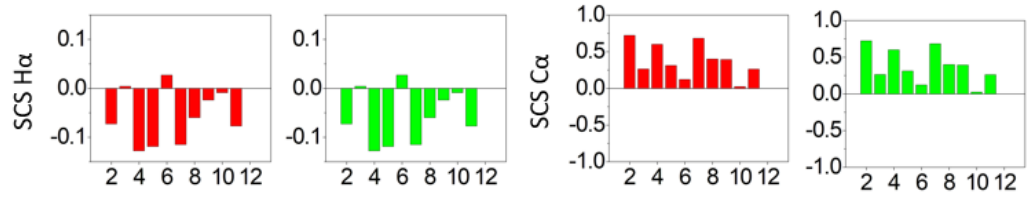

$\mathrm{pH} 7$
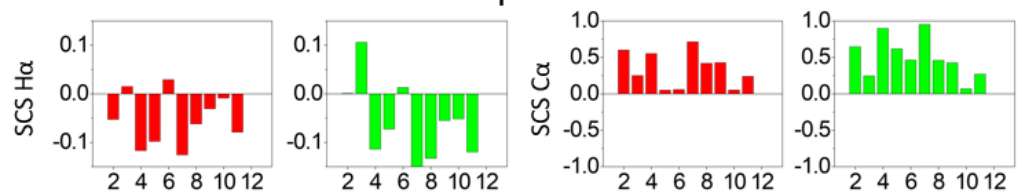

Figure S7. ${ }^{1} \mathrm{H},{ }^{15} \mathrm{~N}-\mathrm{SOFAST}-\mathrm{HMQC}$ spectra of (A) (6)-Cf-ERD-A and (B) 5-Cf-ERD-A at different $\mathrm{pH}$ values: $\mathrm{pH}=3$ (red), 5 (blue) and 7 (purple). (C) Calculated secondary chemical shifts for $\mathrm{H} \alpha$ and $\mathrm{C} \alpha$ atoms for (6)-Cf-ERD-A (red) and (5)-Cf-ERD-A (green) at $\mathrm{pH}=3,5$ and 7. 
Figure S8. $\mathrm{pH}$ dependency of (5)- and (6)-Cf-ERD-B peptides

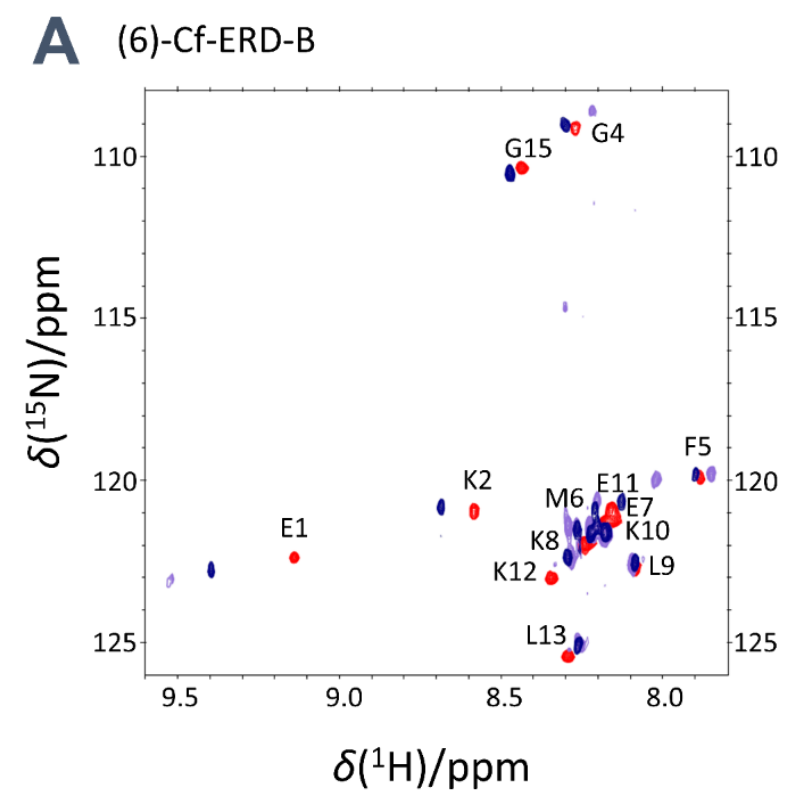

B (5)-Cf-ERD-B

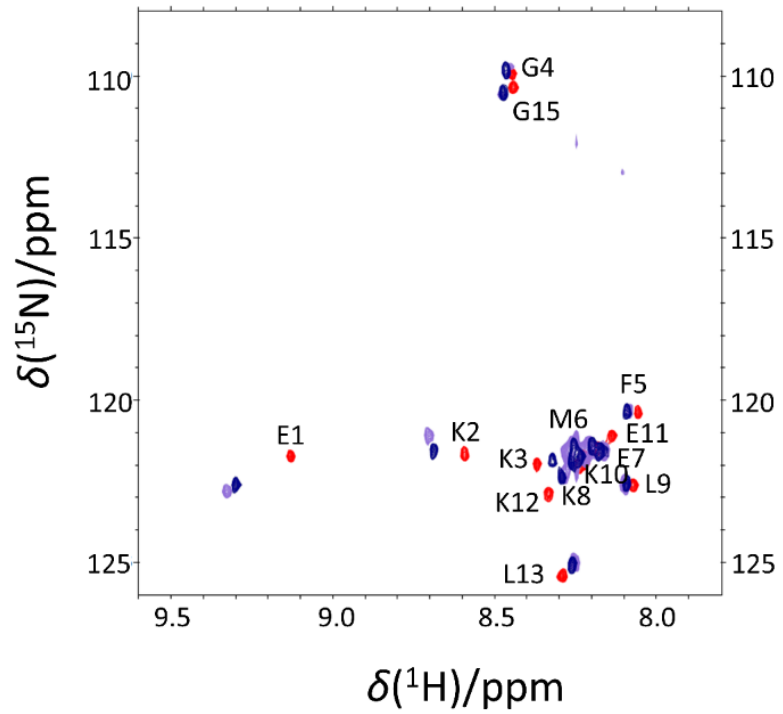

C ERD-B

$\mathrm{pH} 3$
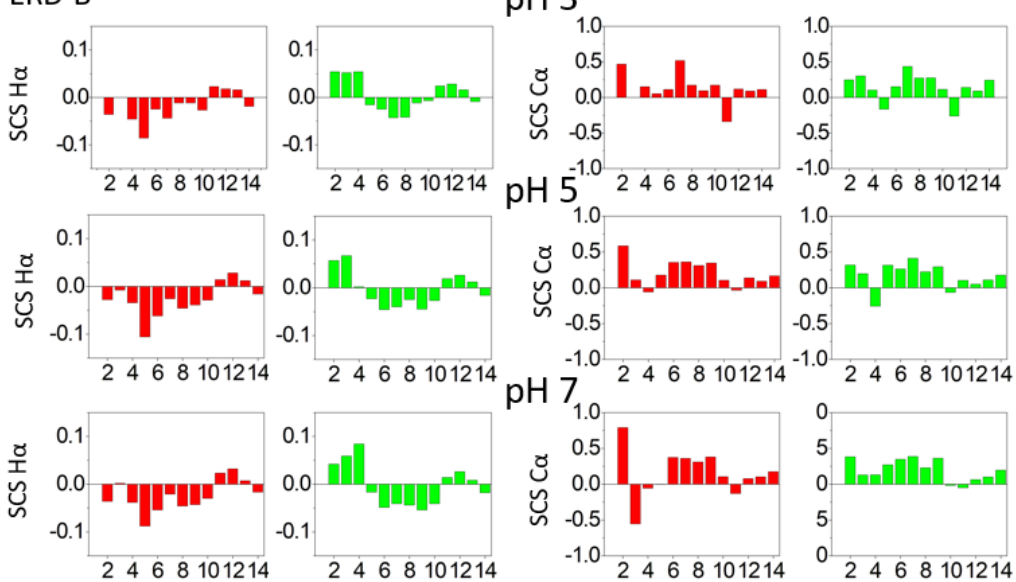

Figure S8. ${ }^{1} \mathrm{H},{ }^{15} \mathrm{~N}$-SOFAST-HMQC spectra of (A) (6)-Cf-ERD-B and (B) (5)-Cf-ERD-B at different $\mathrm{pH}$ values: $\mathrm{pH}=3$ (red), 5 (blue) and 7 (purple). (C) Calculated secondary chemical shifts for $\mathrm{H} \alpha$ and $\mathrm{C} \alpha$ atoms for (6)-Cf-ERD-B (red) and (5)-Cf-ERD-B (green) at $\mathrm{pH}=3,5$ and 7. 


\section{S4. In vitro cellular uptake and internalization studies of Cf-conjugated peptide derivatives}

During the preliminary studies MonoMac6 human monocytic leukemia cells and A431 human skin squamous cell carcinoma culture were treated with the Cf-peptides at a concentration range 6.25-50 $\mu \mathrm{M}$, for 3 hours.

The cellular localization of the Cf-conjugates first was accessed via extended trypsinization and was followed by flow cytometry and CLSM. In the case of MonoMac6 cells, 2 or 4 min of trypsinization was used to detach the cells. With an elevated incubation time, the extracellular (membrane bound) localization of the peptides can be monitored. Using 4 min of trypsinization have not changed the fluorescence intensity values. This observation was also confirmed on the CLSM images.

Figure S9. In vitro cellular uptake on MonoMac6 cells
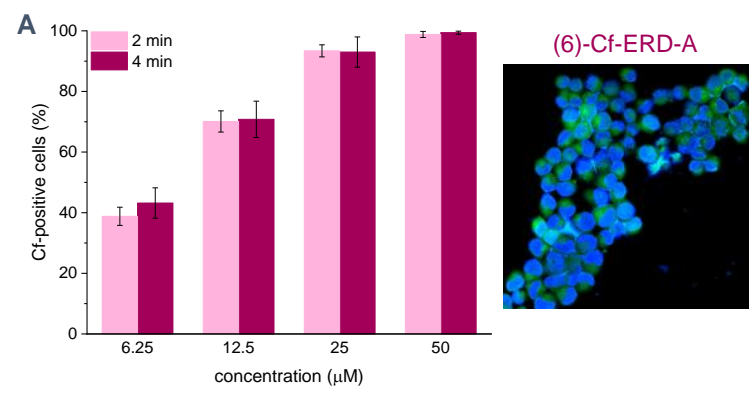

B
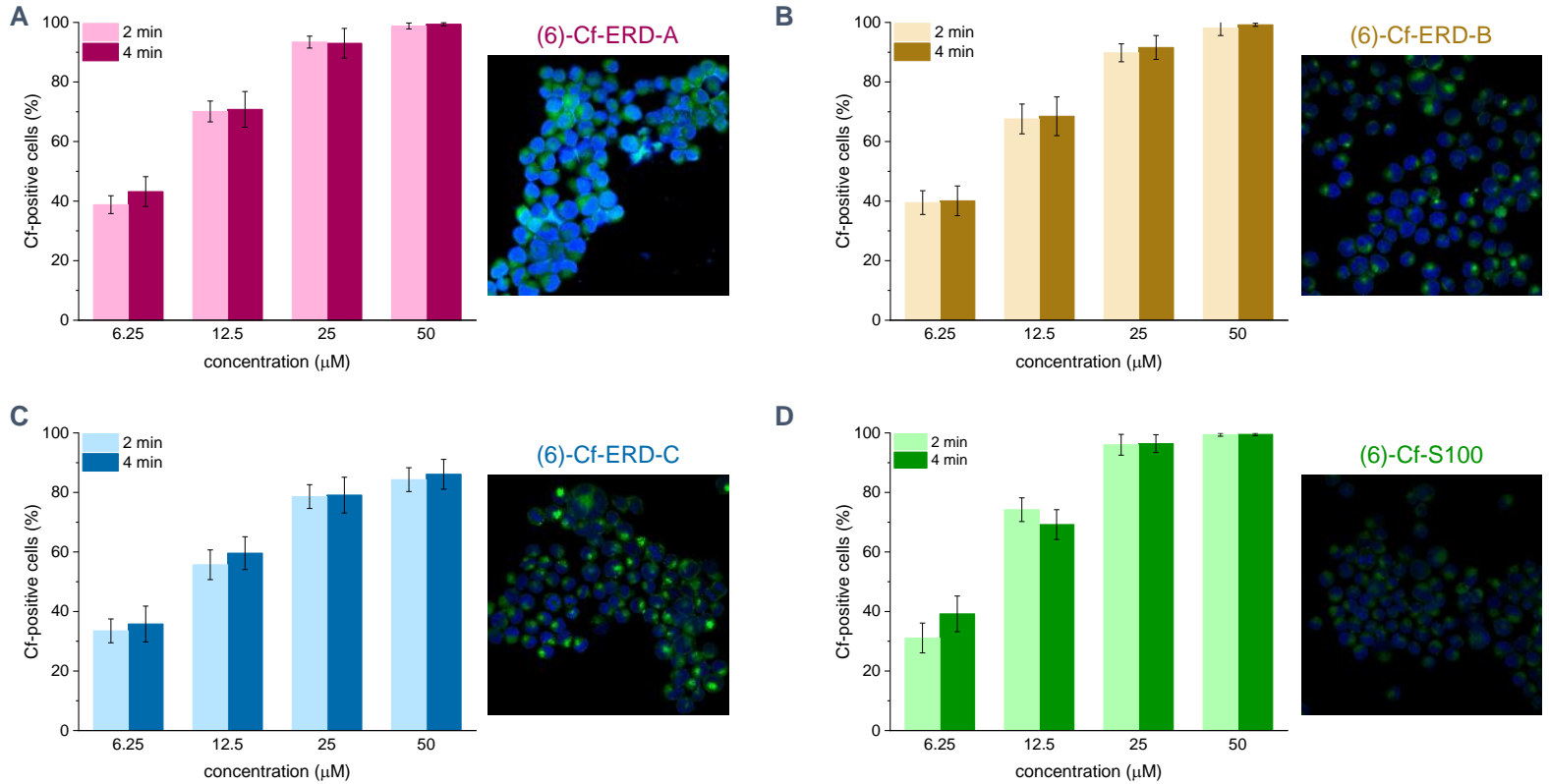

(6)-Cf-ERD-C
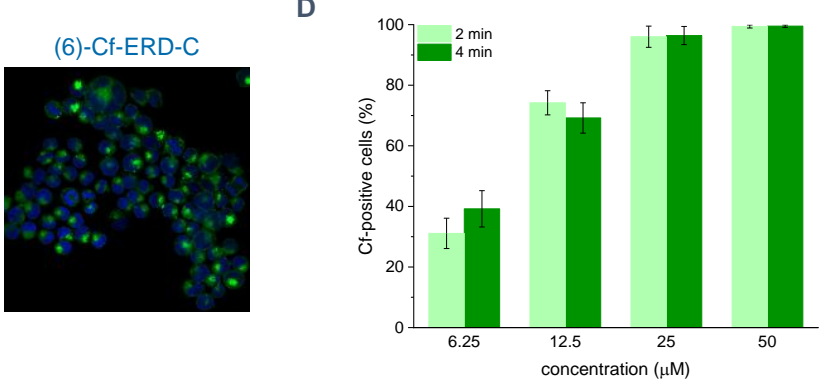

(6)-Cf-S100

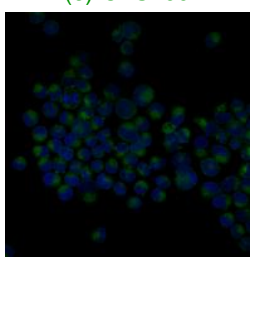

Figure S9. Internalization of the Cf-peptides on MonoMac6 cells measured by flow cytometry (6.25$50 \mu \mathrm{M}, 3$ hours) and confocal microscopy (50 $\mu \mathrm{M}, 3$ hours) with different trypsinization times. Cell nuclei Hoechst 33342, blue, Cf-peptides green. (A) (6)-Cf-ERD-A, (B) (6)-Cf-ERD-B, (C) (6)-Cf-ERDC, (D) (6)-Cf-S100. Graphs present the ratio of Cf-positive live cells, error bars correspond to SEM. 
A431 cells were trypsinized for $4 \mathrm{~min}$ or $8 \mathrm{~min}$ and in this case with an elevated incubation time membrane bound localization of the peptides was detected. Using $8 \mathrm{~min}$ of trypsinization markedly decreased the fluorescence intensity values without decreasing the viability of the cells (data not shown). The decreased signal was also captured by fluorescence microscopy. By extending the incubation time with trypsin, no further decreasing of the fluorescence signal was detected. These observations were also confirmed on the CLSM images.

Figure S10. In vitro cellular uptake rate of Cf-peptides using different incubation times with trypsin on A431 cells

A

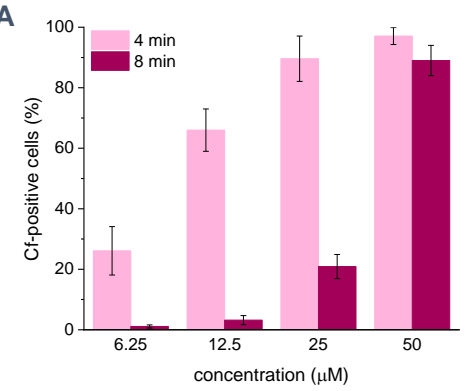

C

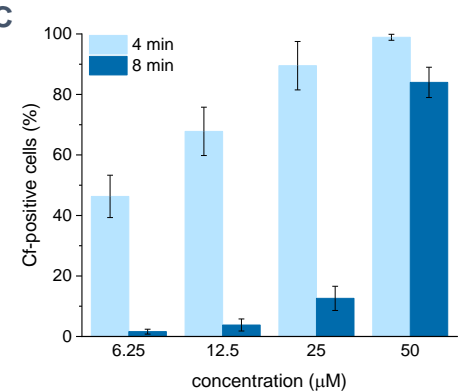

(6)-Cf-ERD-A

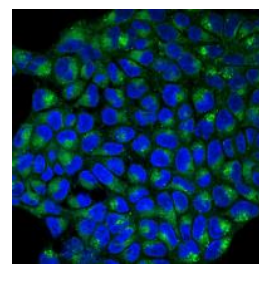

(6)-Cf-ERD-C

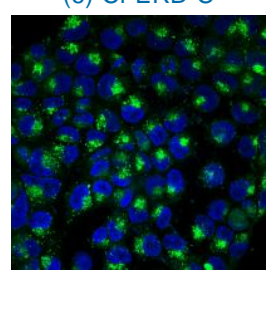

B

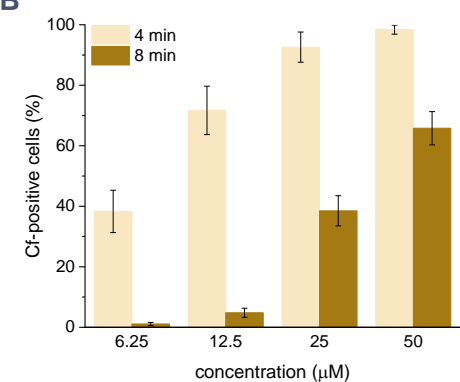

D

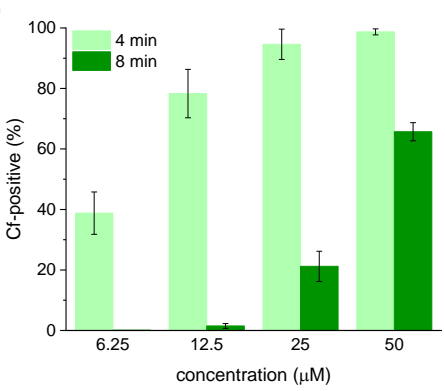

(6)-Cf-ERD-B

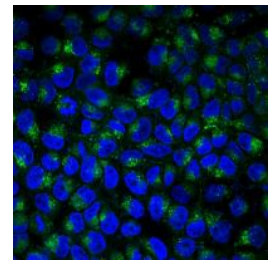

(6)-Cf-S100

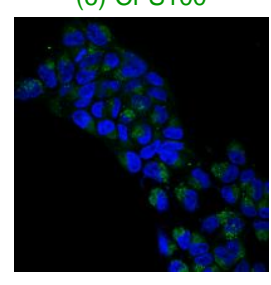

Figure S10. Internalization of the Cf-peptides on A431 cells measured by flow cytometry $(6.25-50 \mu \mathrm{M}$, 3 hours) and confocal microscopy ( $50 \mu \mathrm{M}, 3$ hours). A431 cells were trypsinized for 4 min or 8 min. Cell nuclei Hoechst 33342, blue, Cf-peptides green. (A) (6)-Cf-ERD-A, (B) (6)-Cf-ERD-B, (C) (6)-CfERD-C, (D) (6)-Cf-S100. Graphs present the ratio of Cf-positive live cells, error bars correspond to SEM. 
Trypan blue was also used to distinguish membrane-bound Cf-conjugates from internalized ones by quenching the external fluorescence. This quenching was performed by adding $10 \mu \mathrm{L}$ of $0.04 \%$ trypan blue solution to the cells. Intracellular fluorescence intensity of cells was measured before and after adding trypan blue. Trypan blue is impermeable for living cells and quenches the extracellular green fluorescence, therefore, applying the solution only the internal fluorescence can be detected. No significant difference was observed after eliminating the cellsurface associated fluorescent signal.

Figure S11. In vitro cellular uptake on MonoMac6 cells using trypan blue to quench external fluorescence

A

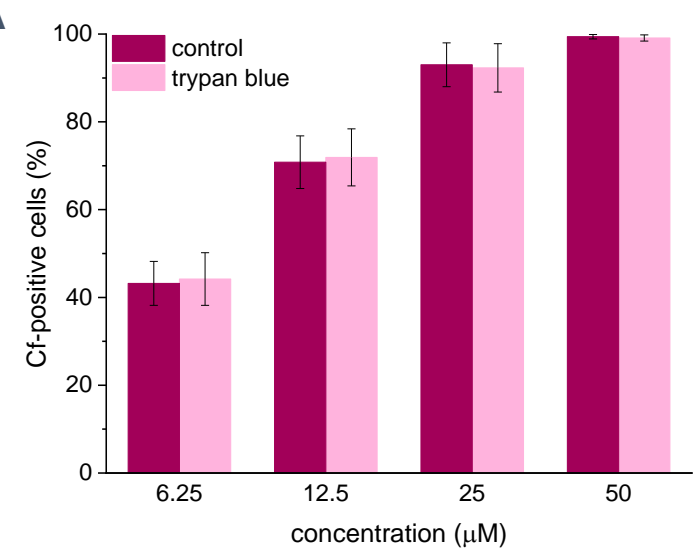

C

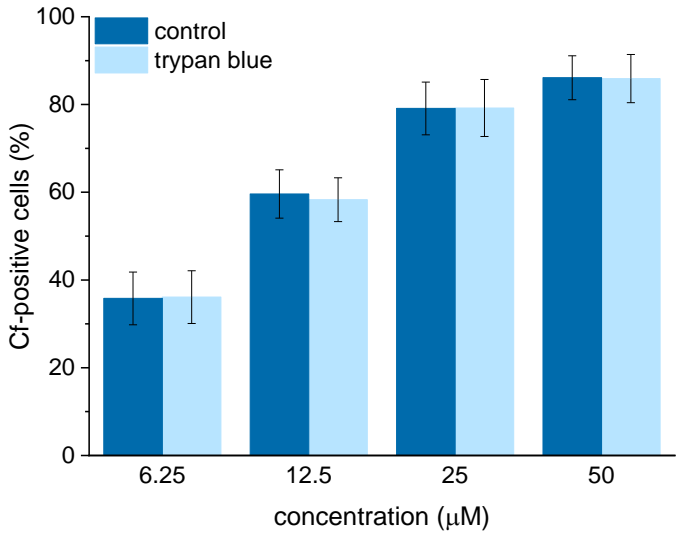

B

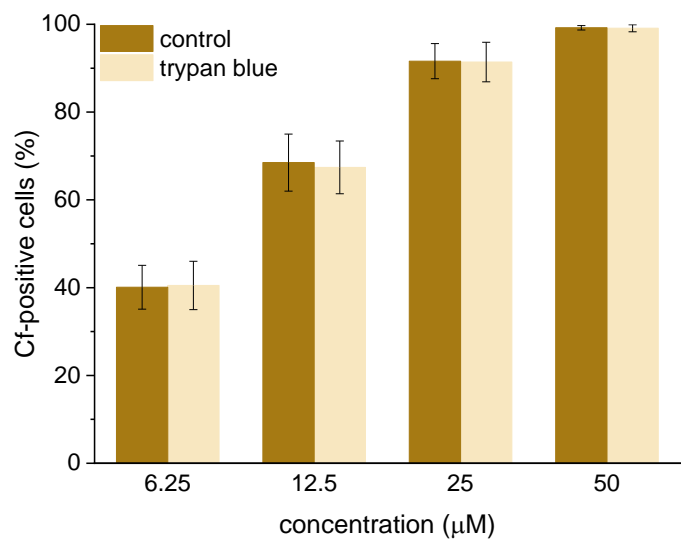

D

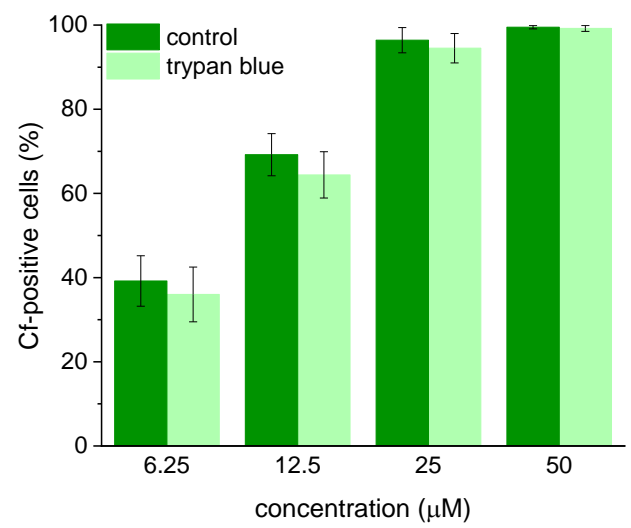

Figure S11. Internalization of the Cf-peptides on MonoMac6 cells determined by flow cytometry (6.25$50 \mu \mathrm{M}, 3$ hours; columns with deeper color) and incubated with $0.04 \%$ trypan blue to detect membrane bound (extracellular) Cf-peptides. (A) (6)-Cf-ERD-A, (B) (6)-Cf-ERD-B, (C) (6)-Cf-ERD-C, (D) (6)Cf-S100. Graphs present the ratio of Cf-positive live cells, error bars correspond to SEM. 
Figure S12. In vitro cellular uptake on A431 cells using trypan blue to quench external fluorescence

A

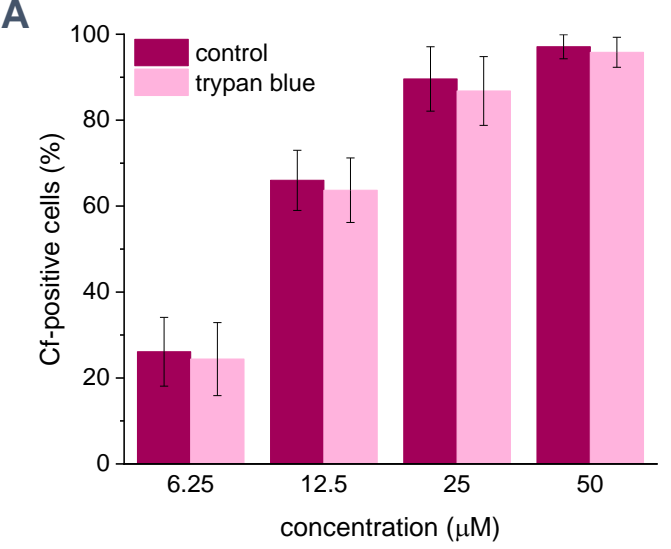

C

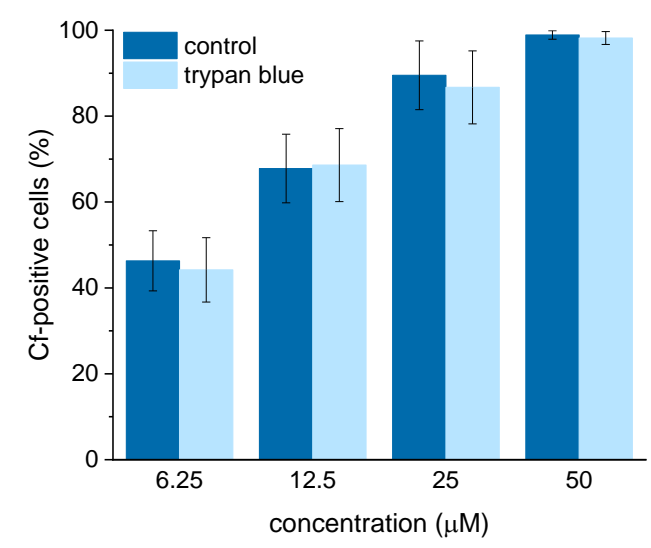

B

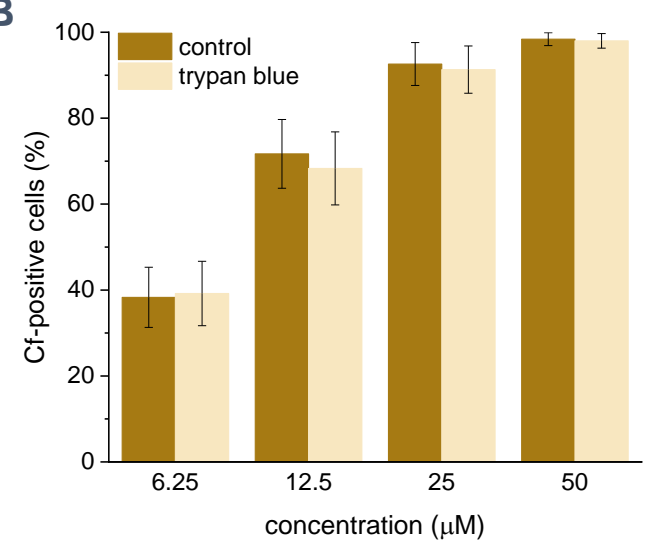

D

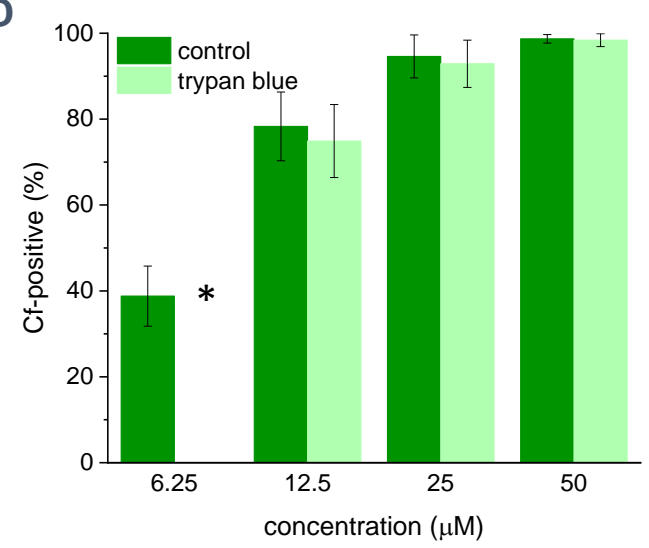

Figure S12. Internalization of the Cf-peptides on A431 cells determined by flow cytometry (6.25$50 \mu \mathrm{M}, 3$ hours, columns with deeper color) and incubated with $0.04 \%$ trypan blue to detect membrane bound (extracellular) Cf-peptides. (A) (6)-Cf-ERD-A, (B) (6)-Cf-ERD-B, (C) (6)-Cf-ERD-C, (D) (6)Cf-S100. * no data. Graphs present the ratio of Cf-positive live cells, error bars correspond to SEM. 
A431 cells were also treated for $1.5 \mathrm{~h}$ (Figure S13 A) and $3 \mathrm{~h}$ (Figure S13 B) to determine the time-dependence of the cellular uptake. In all cases after $3 \mathrm{~h}$ treatment higher cellular uptake can be observed.

Figure S13. Time dependency of cellular uptake on A431 cells

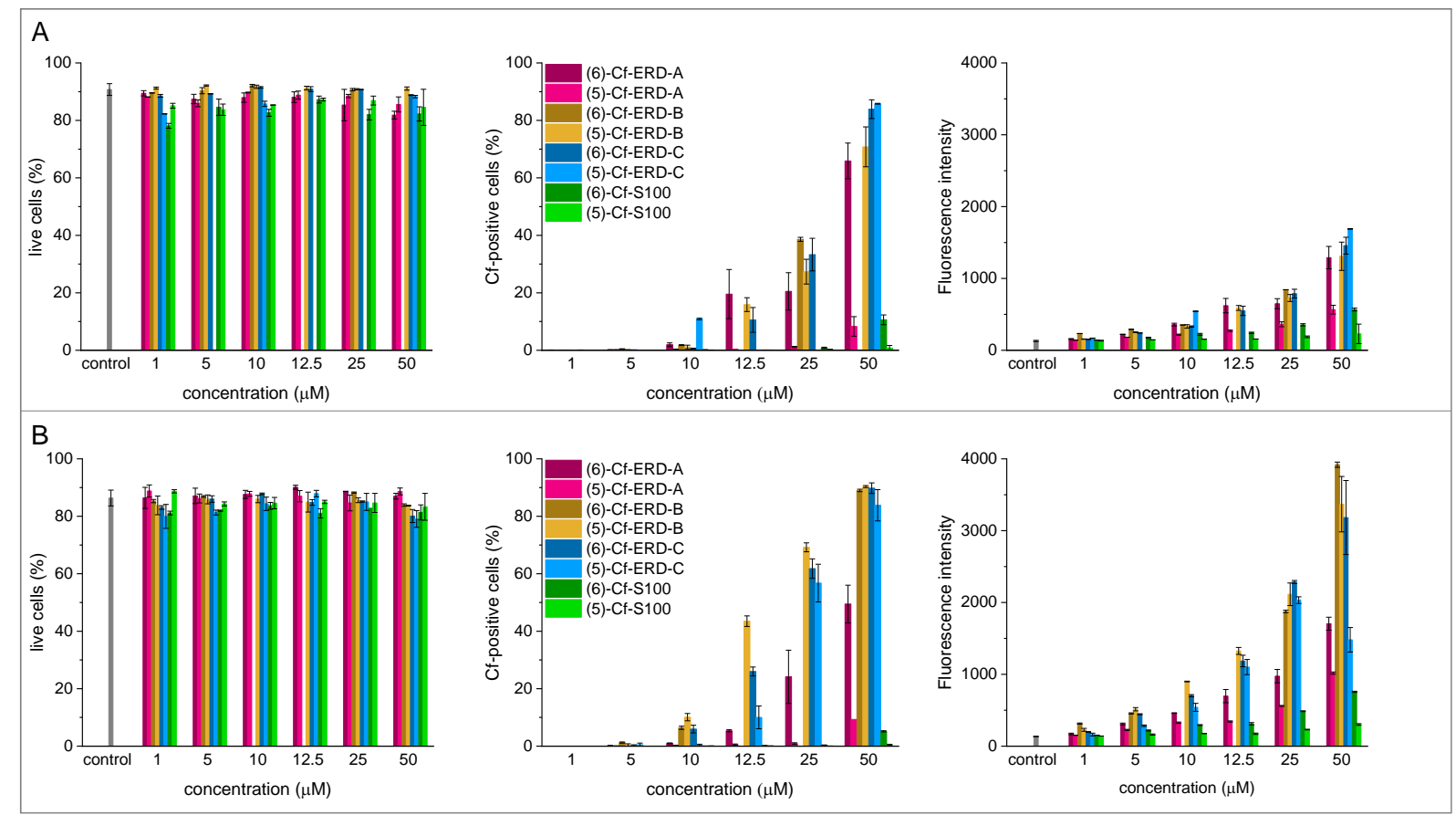

Figure S13. Time dependency of in vitro cellular uptake of the Cf-peptides on A431 cells quantified by flow cytometry. Treatment: 1-50 $\mu \mathrm{M}$, (A) $1.5 \mathrm{~h}$, (B) $3 \mathrm{~h}$. Relative viability of A431 cells compared to untreated control. Cellular uptake of the Cf-peptides: ratio of Cf-positive live cells and mean fluorescence intensity, error bars correspond to SEM. 
Parallel with the preliminary flow cytometry studies confocal laser scanning microscopy (CLSM) examinations were also performed. MonoMac6 (Figure S14) and A431 (Figure S1517) cells were treated with the peptides for 3 hours at a concentration $50 \mu \mathrm{M}$. Cell nuclei were stained with Hoechst $33342(0.5 \mu \mathrm{g} / \mathrm{mL}, 12 \mathrm{~min})$ and cells were fixed with $4 \%$ paraformaldehyde (15 min). Microscopy images were obtained using Zeiss LSM 710 system.

Figure S14. Internalization of Cf-peptides on MonoMac6 cells visualized by CLSM

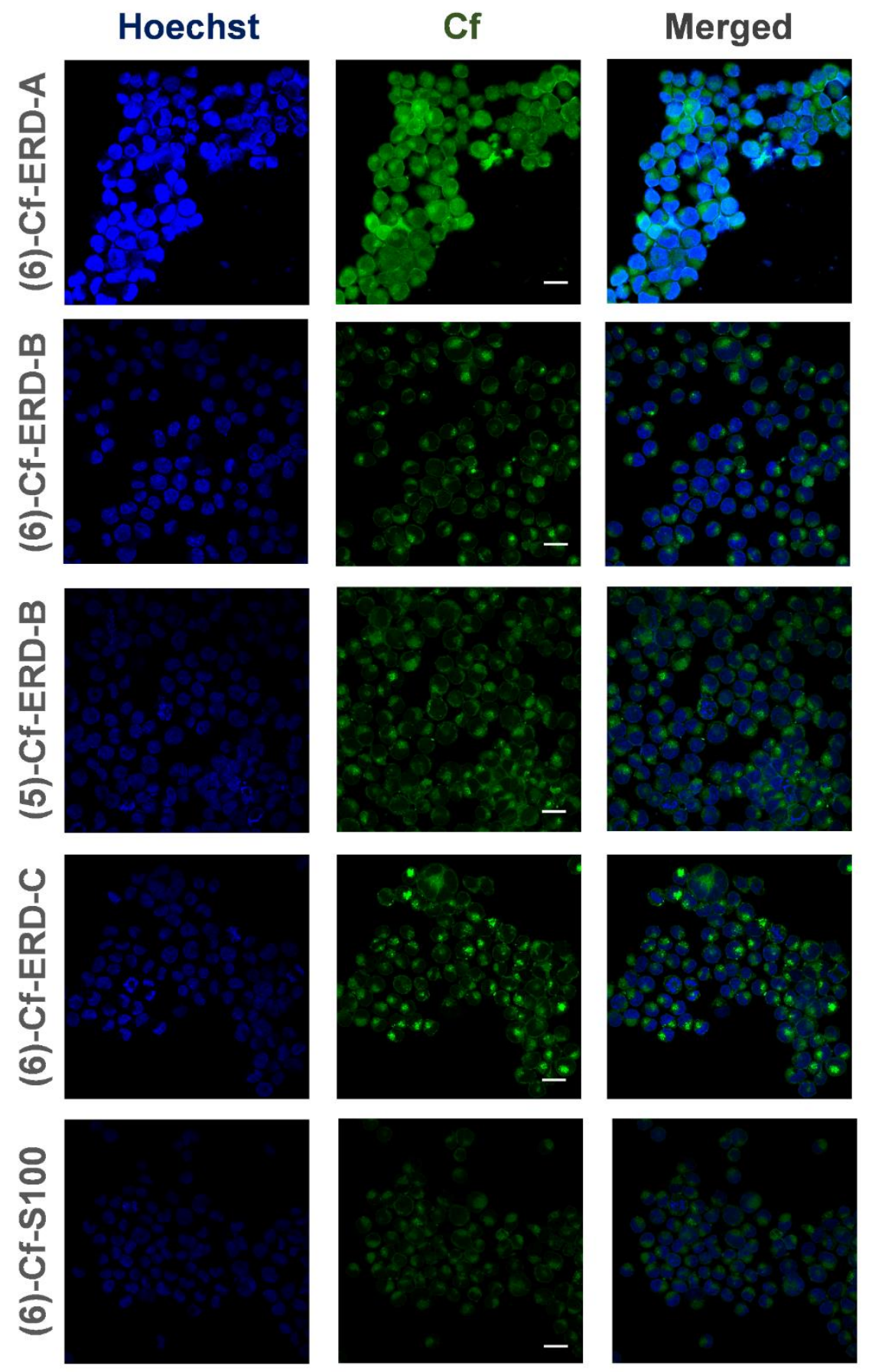

Figure S14. In vitro intracellular localization of Cf-peptides visualized by CLSM. MonoMac6 cells were treated for $3 \mathrm{~h}$ with Cf-peptides $(50 \mu \mathrm{M}$, green). Nuclei were labeled by Hoechst 33342 (blue). Imaging was performed by Zeiss LSM 710 system, scale bar represents $20 \mu \mathrm{m}$. 
Figure S15. Internalization of Cf-peptides on A431 cells visualized by CLSM
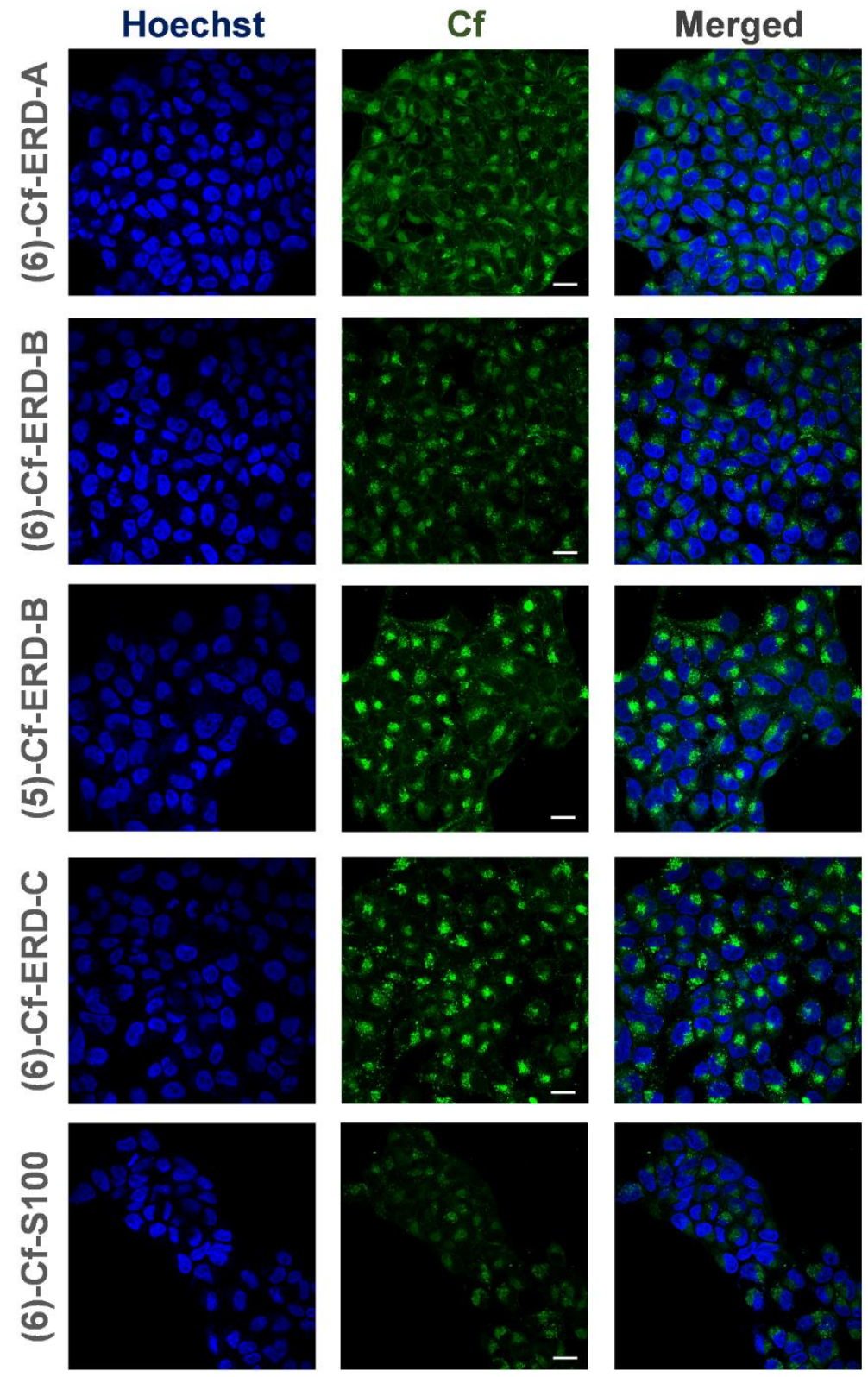

Figure S15. In vitro intracellular localization of Cf-peptides visualized by CLSM. A431 cells were treated for $3 \mathrm{~h}$ with Cf-peptides $(50 \mu \mathrm{M}$, green). Nuclei were labeled by Hoechst 33342 (blue). Imaging was performed by Zeiss LSM 710 system, scale bar represents $20 \mu \mathrm{m}$. 
Figure S16. Intracellular localization of (6)-Cf-peptides on A431 cells visualized by CLSM

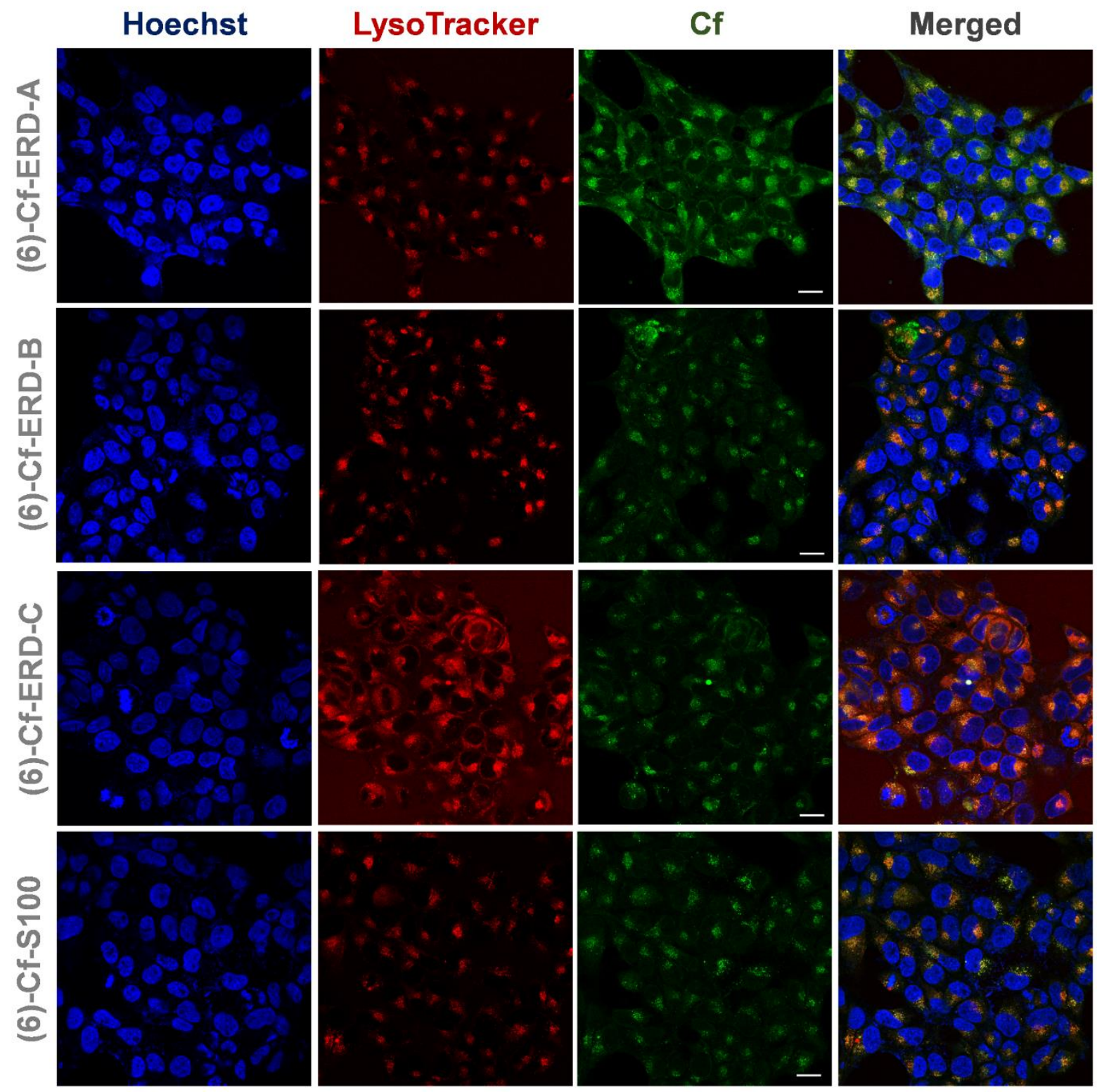

Figure S16. In vitro intracellular localization of (6)-Cf peptides visualized by CLSM. A431 cells were treated for $1.5 \mathrm{~h}$ with Cf-peptides $(25 \mu \mathrm{M}$, green). Lysosomes were stained by LysoTracker Deep Red (100 nM, $30 \mathrm{~min}$, red), nuclei were labeled by Hoechst $33342(0.5 \mu \mathrm{g} / \mathrm{mL}, 12 \mathrm{~min}$, blue) and cells were fixed with $4 \%$ paraformaldehyde (15 min). Imaging was performed by Zeiss LSM 710 system, scale bar represents $20 \mu \mathrm{m}$. 
Figure S17. Intracellular localization of (5)-Cf-peptides on A431 cells visualized by CLSM

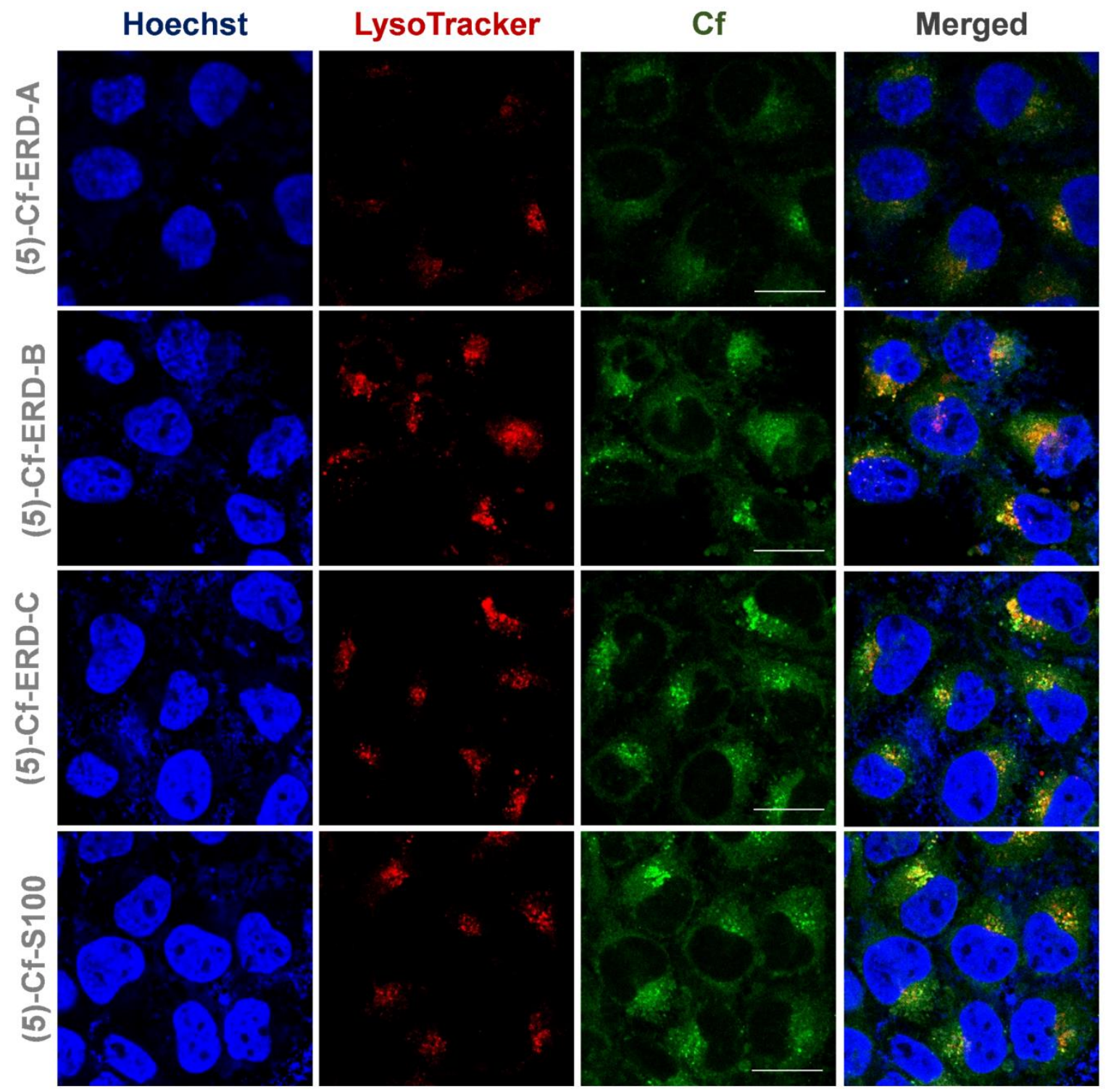

Figure S17. In vitro intracellular localization of (5)-Cf peptides visualized by CLSM. A431 cells were treated for $1.5 \mathrm{~h}$ with Cf-peptides ( $25 \mu \mathrm{M}$, green). Lysosomes were stained by LysoTracker Deep Red (100 nM, $30 \mathrm{~min}$, red), nuclei were labeled by Hoechst $33342(0.5 \mu \mathrm{g} / \mathrm{mL}, 12 \mathrm{~min}$, blue) and cells were fixed with $4 \%$ paraformaldehyde (15 min). Imaging was performed by Zeiss LSM 710 system, scale bar represents $20 \mu \mathrm{m}$. 


\section{S5. In vitro cytotoxic activity of different inhibitor compounds}

In vitro cytotoxic effect of the selected inhibitor compounds was determined using MTT assay and treatment with the concentration ranges: 5-(N-ethyl-N-isopropyl)-amiloride (EIPA) 4 $1000 \mu \mathrm{M}, \beta$-methyl cyclodextrin ( $\beta \mathrm{MCD}) 200 \mu \mathrm{M}$ - $50 \mathrm{mM}$, 2-deoxy-glucose $240 \mu \mathrm{M}-6 \mathrm{mM}$ and Na-azide $0.4-100 \mu \mathrm{M}$ and 3 hours incubation time. $\mathrm{IC}_{50}$ values of the compounds summarized in Table S4. EIPA and $\beta$-methyl-cyclodextrin have cytotoxic effect on A431 cells, in case of compounds causing ATP-depletion no cytotoxic effect was observed. For the inhibition experiments EIPA and $\beta M C D$ were used in a concentration with no cytotoxic effect.

Table S4. In vitro cytotoxic effect of different inhibitors on A431 cells

\begin{tabular}{|c|c|}
\hline Inhibitor & $\mathrm{IC}_{50}$ on $\mathrm{A} 431$ \\
\hline EIPA & $160.1 \pm 34.6 \mu \mathrm{M}$ \\
\hline B-methyl-cyclodextrin & $3.6 \pm 0.1 \mathrm{mM}$ \\
\hline 2-deoxy-glucose* & $>6 \mathrm{mM}$ \\
\hline Na-azide* $^{*}$ & $>100 \mu \mathrm{M}$ \\
\hline
\end{tabular}

*These compounds were used in ATP depletion studies. 


\section{S6. Inhibition of in vitro cellular uptake}

Understanding the internalization mechanisms of the Cf-peptides we carried out inhibition studies. Inhibitor compounds (EIPA, $\beta M C D$, 2-deoxy-glucose and Na-azide) were added prior the treatment with $\mathrm{Cf}$-peptides for $60 \mathrm{~min}$. The following concentrations were used: EIPA 50 $\mu \mathrm{M}, \beta \mathrm{MCD}$ : $2 \mathrm{mM}$, 2-deoxy-glucose $25 \mathrm{mM}$ and Na-azide $50 \mu \mathrm{M}$ (for ATP-depletion). Peptides were added to the cells at $25 \mu \mathrm{M}$ for 1.5 hours.

Figure S18. Chemical inhibition of in vitro cellular uptake on A431 cells determined by flow cytometry
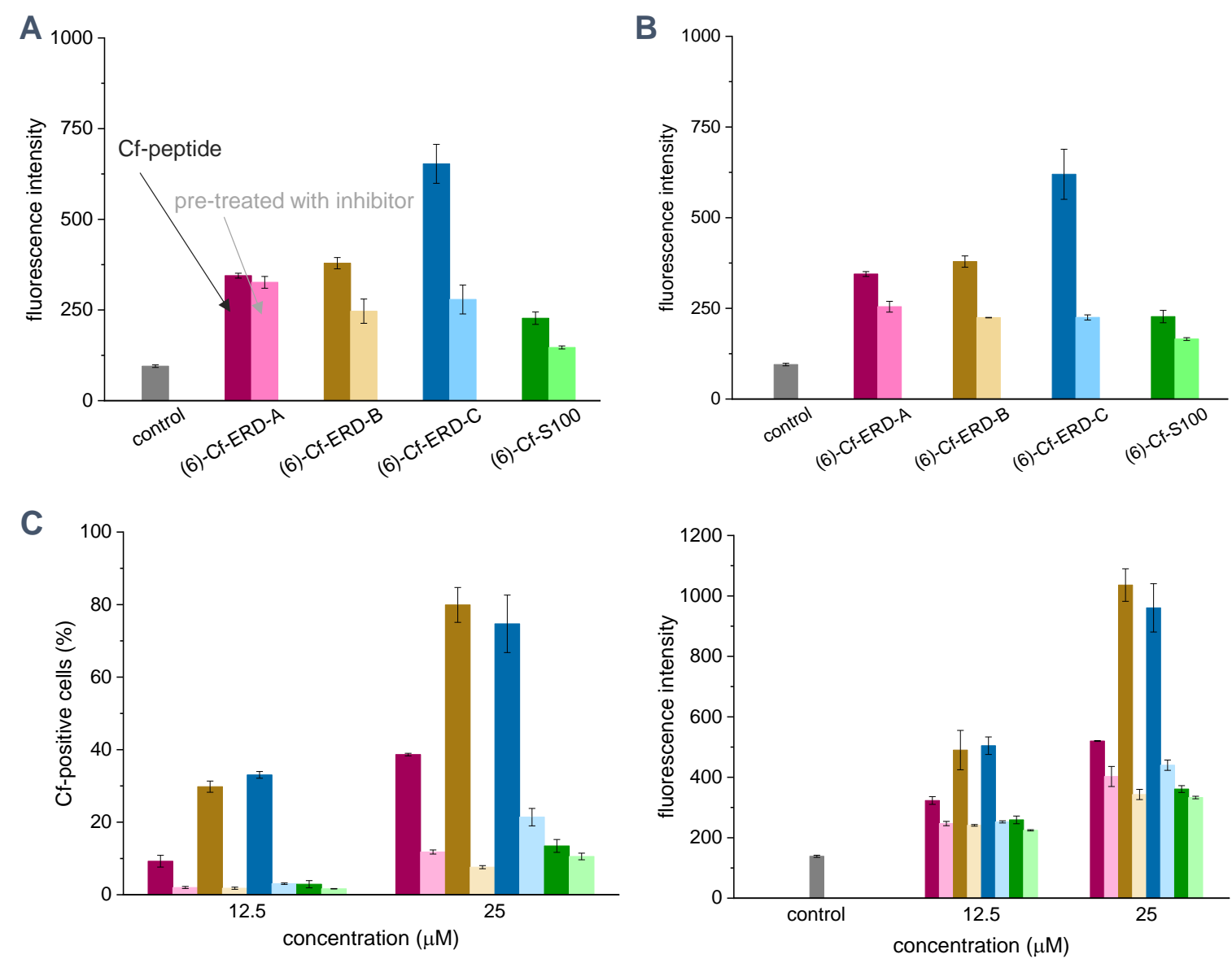

Figure S18. Internalization of the Cf-peptides into A431 cells measured by flow cytometry. Cellular uptake of the Cf-peptides without (deeper color) and with inhibitor compounds (A) $50 \mu \mathrm{M}$ EIPA, (B) 2 mM $\beta$ MCD, (C) ATP-depletion: $25 \mathrm{mM}$ 2-deoxy-glucose and $50 \mu \mathrm{M}$ Na-azide; mean fluorescence intensity and ratio of Cf-positive live cells. Inhibitor compounds were added prior the treatment with peptides $60 \mathrm{~min}$ at $37^{\circ} \mathrm{C}, 5 \% \mathrm{CO}_{2}$ humified atmosphere. The treatment with the Cf-peptides: $25 \mu \mathrm{M}$, 1.5 hours. Error bars correspond to SEM. 
Figure S19. Suggested internalization paths and in vitro cellular uptake determined at low temperature $\left(4^{\circ} \mathrm{C}\right)$

A

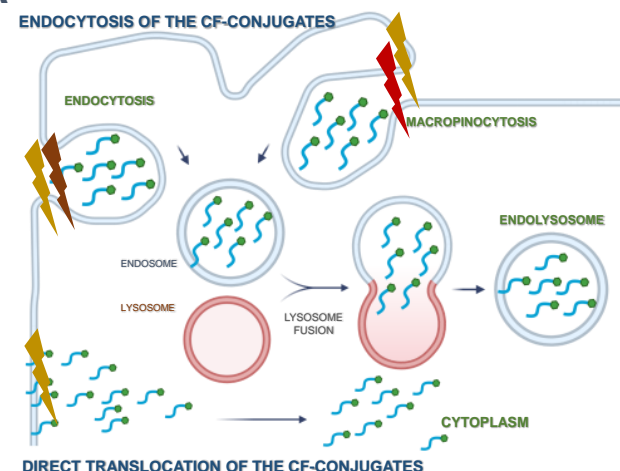

C

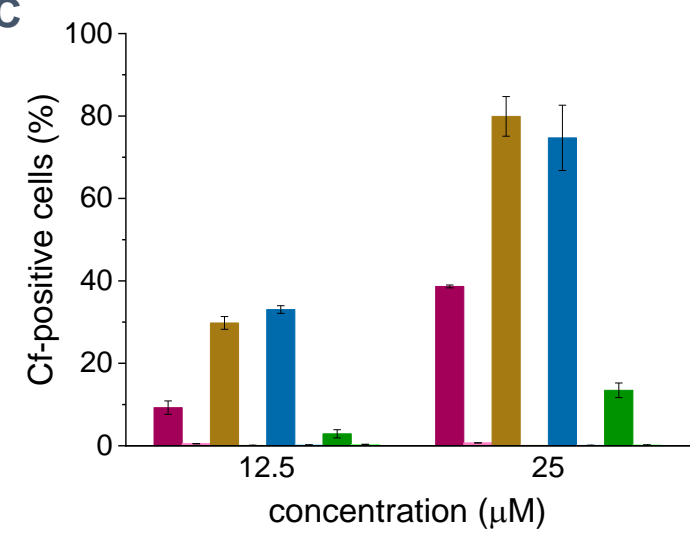

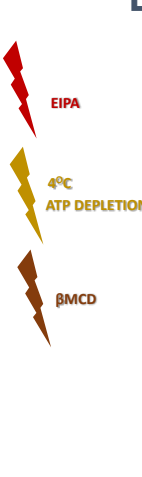

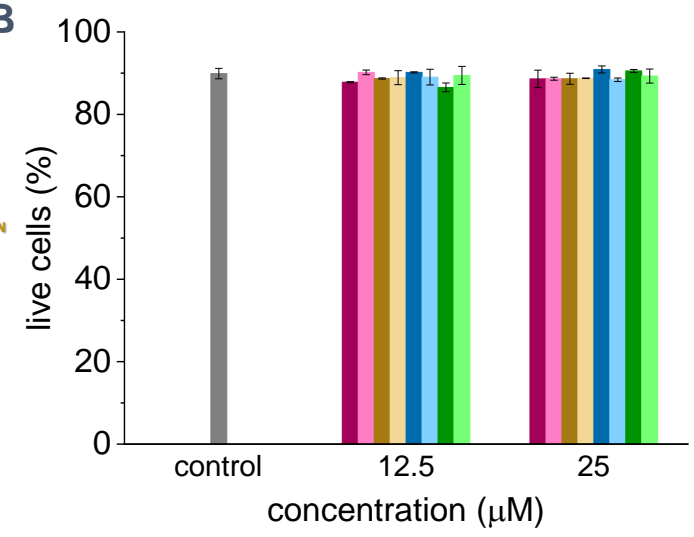

D

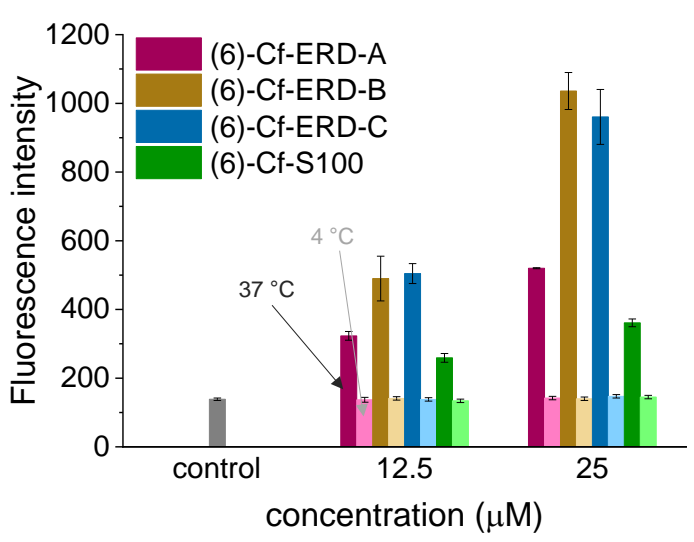

Figure S19. Suggested internalization paths of the Cf-peptides into A431 cells (A). Cellular uptake of Cf-peptides quantified by flow cytometry (B), (C), (D). Cells were treated at low temperature $\left(4{ }^{\circ} \mathrm{C}\right)$ with the Cf-peptides at 12.5 and $25 \mu \mathrm{M}$ for 1.5 hours. As control, cells were treated with the same concentrations and treating time at $37^{\circ} \mathrm{C}$ (deeper color) (See Figure S13 for initial measurements). (A) ratio of living cells, (B) ratio of Cf-positive cells, (C) mean fluorescence intensity, error bars correspond to SEM. 


\section{References}

1. Wei, L.; Tang, J.; Zou, Q. SkipCPP-Pred: an improved and promising sequence-based predictor for predicting cell-penetrating peptides. BMC Genomics 2017, 18, 742.

2. Sabnis, R. W. Handbook of Fluorescent Dyes and Probes, 1st ed.; John Wiley \& Sons, Inc: Hoboken, New Jersey, 2015; pp 110-118 